\begin{tabular}{|c|c|c|c|}
\hline Article Info & RESEARCH ARTICLE & ARAŞTIRMA MAKALESI & \\
\hline Title of Article & \multicolumn{2}{|c|}{$\begin{array}{c}\text { An Index Method in Sustainable Landscape } \\
\text { Design Evaluation }\end{array}$} & \\
\hline $\begin{array}{l}\text { Corresponding } \\
\text { Author }\end{array}$ & \multicolumn{2}{|c|}{$\begin{array}{l}\text { Fatma AŞILIOĞLU } \\
\text { Ankara Üniversitesi, Kalecik Meslek Yüksekokulu, Peyzaj ve Süs Bitkileri Programı, } \\
\text { fatma.asilioglu@ankara.edu.tr }\end{array}$} & \\
\hline $\begin{array}{l}\text { Received Date } \\
\text { Accepted Date }\end{array}$ & \multicolumn{2}{|l|}{$\begin{array}{l}14.08 .2021 \\
20.08 .2021\end{array}$} & \\
\hline DOI number & \multicolumn{2}{|l|}{ https://doi.org/10.35674/kent.982854 } & \\
\hline Author / Authors & Fatma AŞILIOĞLU & ORCID: 0000-0001-9869-9638 & \\
\hline How to Cite & \multicolumn{2}{|c|}{$\begin{array}{l}\text { Aşılığlu, F. (2021). An Index Method in Sustainable Landscape Design Evaluation / } \\
\text { Sürdürülebilir Peyzaj Tasarımı Değerlendirmesinde Bir Katsayı Yöntemi, Kent } \\
\text { Akademisi, Volume, 14, Issue 3, Pages, 616-633. }\end{array}$} & $\begin{array}{l}\text { Kent Akademisi } \\
\text { Urban Academy }\end{array}$ \\
\hline
\end{tabular}

\title{
Sürdürülebilir Peyzaj Tasarımı Değerlendirmesinde Bir Katsayı Yöntemi
}

\begin{abstract}
:
Parks are important components of the built environment in the settlements and should be designed and improved to protect the functions in the long term. The aim of this study is to develop a method that quantitates the sustainability levels of park designs. The study was carried out in three parks, namely Şehitler Park, Osman Arslan Park and Atatürk Park, in Kalecik district of Ankara. First of all, the criteria determined by the SITES rating system for the land design were examined and regulated by considering regional conditions. In this context, four main criteria, including soil and vegetation, material selection, water, human health and well-being, and 30 sub-criteria were evaluated. The Simos procedure was used to assign weight to criteria and the 5-likert scale was used to establish the suitability scores. Sustainable Landscape Design Index (SLDI) was calculated for each park and each sub-criteria with various equations. SLDI values expressing sustainability levels of parks were given and interpreted in tables and diagrams. Accordingly, one of the parks has the highest SLDI average in terms of the main criterion of the water and the other two of the soil and vegetation. SLDI values for human health and well-being are at the lowest level in all parks. When the sub-criteria were examined, it was seen that the three parks reached the highest SLDI value in three different sub-criteria, including the suitable plant use, reducing the use of wood material produced from threatened species and an efficient irrigation system, and the lowest SLDI value in the sub-criteria of providing smokeless airspace. The study revealed a comprehensive, comparable and reproducible index method that quantitates the sustainability levels of existing parks. The method is expected to be used as a measurement tool in the creation of new parks suitable for sustainable design and the renovation of existing parks.
\end{abstract}

KEYWORDS: Sustainable Landscape Design Index, SLDI, SITES Rating System, Simos procedure

${ }^{1}$ Ankara Üniversitesi, Kalecik Meslek Yüksekokulu, Peyzaj ve Süs Bitkileri Programı, fatma.asilioglu@ankara.edu.tr Sürdürülebilir Peyzaj Tasarımı Değerlendirmesinde Bir Katsayı Yöntemi Journal of Urban Academy | Volume: 14 Issue: 3 | ISSN: 2146-9229

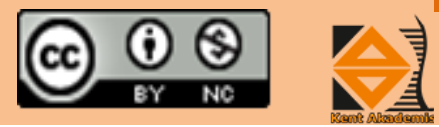


ÖZ:

Sürdürülebilirlik insan sağlı̆̆ı, çevre ve doğal kaynaklar üzerinde etkilere sahip birçok alanda olduğu gibi peyzaj tasarımında da önemli ve güncel kavramlardan biridir. Dünyada sürdürülebilir tasarımları değerlendirmek üzere oluşturulmuş çok sayıda derecelendirme sistemi vardır. Bu sistemlerin çoğu, yapı ve açık alan tasarımlarının sürdürülebilirlik düzeylerini ölçen nicel analizlere dayanmaktadır. Parklar, yerleşim merkezlerindeki yapılı çevrenin önemli bileşenlerindendir ve işlevlerini uzun vadede korumak üzere tasarlanmalı ve geliştirilmelidir. Bu çalışmanın amacı park tasarımlarının sürdürülebilirlik düzeylerini nicel olarak ifade eden bir yöntem geliştirmektir. Çalışma Ankara ili Kalecik ilçesinde Şehitler Parkı, Osman Arslan Parkı ve Atatürk Parkı olmak üzere üç parkta yürütülmüştür. Öncelikle SITES Derecelendirme Sisteminin alan tasarımı için belirlediği kriterler incelenmiş ve bölgesel koşullar dikkate alınarak düzenlenmiştir. Bu kapsamda toprak ve vejetasyon, materyal seçimi, su, insan sağlığı ve refahı olmak üzere dört ana kriter ve bunların kapsadığ 130 alt kriter değerlendirmeye alınmıştır. Kriterlere ağırlık tayin etmede Simos prosedürü, uygunluk puanlarının verilmesinde ise 5'li Likert ölçeği kullanılmıştır. Çeşitli eşitliklerle her bir park ve her bir alt kriter için Sürdürülebilir Peyzaj Tasarımı Katsayısı (Sustainable Landscape Design Index, SLDI) hesaplanmıştır. Parkların sürdürülebilirlik düzeylerini ifade eden SLDI değerleri tablo ve diyagramlar halinde verilmiş ve yorumlanmıştır. Buna göre parklardan biri su, diğer ikisi ise toprak ve vejetasyon ana kriteri bakımından en yüksek SLDI ortalamasına sahiptir. Tüm parklarda insan sağllğı ve refahına ilişkin SLDI değerleri en düşük düzeydedir. Alt kriterler incelendiğinde ise üç parkın uygun bitki kullanımı, tehdit altındaki türlerden üretilen ahşap materyal kullanımını azaltma ve randımanlı sulama sistemi olmak üzere üç farklı alt kriterde en yüksek, dumansız hava sahası sunma alt kriterinde ise en düşük SLDI değerine ulaştığı görülmüştür. Çalışma, mevcut parkların sürdürülebilirlik düzeylerini nicel olarak ifade eden, anlaşılır, karşılaştırılabilir ve tekrarlanabilir bir katsayı yöntemi ortaya koymuştur. Yöntemin, sürdürülebilir tasarıma uygun yeni parkların oluşturulması ve mevcutların yenilenmesinde bir ölçüm aracı olarak kullanılması beklenmektedir.

ANAHTAR KELIMELER: Sürdürülebilir Peyzaj Tasarımı Katsayısı, SLDI, SITES Derecelendirme Sistemi, Simos prosedürü

\section{GİRIŞ:}

Sürdürülebilir planlama ve tasarım anlayışı, konutların yapım ve kullanım süresi boyunca insan sağlığına duyarlı ve çevresel etkileri minimum olan, uzun ömürlü ekonomik yapıların inşası için ortaya çıkmıştır (Ünal, 2014). Peyzaj tasarımı insanın varoluşu ile görülmeye başlayan küçük ölçekli bahçelerden, sosyal yerleşimlerin artması ile ortaya çıkan geniş ölçekli alanlara kadar uzanmaktadır. Sürdürülebilirlik kavramı, çevre kirliliğinin artması, hammadde kaynaklarının tükenmesi ve doğanın kendini yenileyememesi gibi faktörler nedeniyle peyzaj mimarlığı disiplininin önemli konularından biri haline gelmiştir (Yaşar ve Düzgüneş, 2013). İnsan ve doğanın bütünleşmesini ve aynı zamanda sosyal, ekonomik ve kültürel değerlerin sürdürülebilir gelişimini sağlamayı amaçlayan sürdürülebilir peyzaj tasarımı, sosyal uygunluk, çevreye uyumluluk ve ekonomik fizibilite olmak üzere üç temel unsura sahiptir (Aşılıoğlu, 2016; Dong-dong vd., 2009). Peyzaj mimarlığı pratiğindeki temel eğilim, başarılı bir sürdürülebilir tasarım için estetik ve fonksiyon dengesini kurmak yönündedir (Bean ve Yang, 2016). Kaliteli bir sürdürülebilir tasarım, belirli bir konum veya bölgeye uygun, estetik, işlevsel, sürdürülebilir ve maliyet tasarrufu sağlayan peyzajlar oluşturmayı amaçlar. Ancak bu yaklaşımla kısa ve uzun vadede maksimum düzeyde sürdürülebilir peyzajlar elde edilebilir (Aşılıoğlu, 2016; Cook ve VanDerZanden, 2011).

Dünyada sürdürülebilir tasarımları sertifikalandırmak üzere oluşturulmuş çok sayıda derecelendirme sistemi vardır (Gürbüz ve Arıdağ, 2013; Özyılmaz Küçükyağc1, 2020; Reed vd., 2009; Şenol, 2019). Bu sistemler yap1 ve alan tasarımlarının neden olduğu çevre sorunlarını belirleme, bunlara dikkat çekme ve çevre üzerindeki yıkıcı etkileri azaltma yolunda önemli araçlardır (Kats, 2003; Özyılmaz Küçükyağc1, 2020; Turner vd., 2008). Sürdürülebilir peyzajları desteklemek için 2005 yılında Amerikan Peyzaj Mimarları Topluluğunun (American Society of Landscape Architects, ASLA) önderliğinde Sürdürülebilir Alanlar Girişimi (The Sustainable Sites Initiative) oluşturulmuştur (Gürbüz ve Arıdağ, 2013). 
Austin Texas Üniversitesi Lady Bird Johnson Merkezi ve Amerika Birleşik Devletleri Botanik Bahçesinin de içinde olduğu girişim, ortak ve disiplinler arası bir çabayla SITES Derecelendirme Sistemini (SITES Rating System) geliştirmiştir (SITES, 2014). "SITES, sürdürülebilir ve uyarlanabilir alan geliştirme projeleri oluşturmak için en kapsamlı sistemdir" ve "Peyzaj mimarları, tasarımcılar, mühendisler, planlamacılar, ekologlar, mimarlar, geliştiriciler, politika yapıcılar ve diğerleri tarafından alan geliştirme ve yönetimini yenilikçi sürdürülebilir tasarım ile uyumlu hale getirmek için kullanılmaktadır" (The Sustainable SITES Initiative, 2021).

$\mathrm{Bu}$ çalışmada parkların sürdürülebilir peyzaj tasarımına uygunluk düzeylerini belirleyen nicel bir yöntemin geliştirilmesi hedeflenmiştir. Çalışma Ankara ili Kalecik ilçesinde Şehitler Parkı, Osman Arslan Parkı ve Atatürk Parkı olmak üzere üç parkta yürütülmüş, parklar SITES (2014) rehberinde alan tasarımı başlığı altında bulunan toprak ve vejetasyon; materyal seçimi; su; insan sağlığı ve refahı üzere dört ana kriter ve bunların kapsadığ 30 alt kriter bakımından değerlendirilmiştir. Kriterlere ağırlık tayin etmede Simos prosedürü, uygunluk puanlarının verilmesinde ise 5'li Likert ölçeği kullanılmak suretiyle Sürdürülebilir Peyzaj Tasarımı Katsayısı (Sustainable Landscape Design Index, SLDI) değerleri hesaplanmıştır. Her park için SLDI kapsamında değerlendirme yapılmış, sonuçları ifade eden diyagramlar oluşturulmuş ve yorumlanmıştır.

Çalışmanın yöntemi, bulguları ve elde edilen SLDI değerleri mevcut parkların sürdürülebilir peyzaj tasarımı ilkelerini ne derecede karşıladığını ortaya koymak açısından önemlidir. Yöntemin uygulanması sonucunda parkların ve diğer alanların sürdürülebilirlik ilkeleri doğrultusunda tasarlanması ve mevcutların yine bu doğrultuda revize edilmesi veya dönüştürülmesi için ölçülebilir çıtılar elde edilmiştir. Çünkü SITES'a (2014) göre açı alanlar, yapılı çevrenin önemli bileşenleridir ve fonksiyonel peyzajların sağladığı faydaları korumak ve geliştirmek için planlanabilir, tasarlanabilir, geliştirilebilir ve sürdürülebilir. Bu sayede çevreye olduğu kadar mülk sahiplerine, halka ve ekonomilere de fayda sağlanmış olacaktır.

\section{MATERYAL}

Çalışma Türkiye'nin başkenti Ankara'nın ilçelerinden biri olan Kalecik'in ilçe merkezinde yürütülmüştür. Kalecik Ankara'nın kuzeydoğusunda ve Ankara'ya $70 \mathrm{~km}$ uzaklıkta yer alan, 57 mahalleye, yaklaşık $1318 \mathrm{~km}^{2}$ yüzölçümüne ve TÜİK (2020) verilerine göre 12.941 nüfusa sahip bir ilçedir. Ekonomisi tarım ve hayvancıllk üzerine kuruludur.

Ankara'nın en eski yerleşim bölgelerinden olan Kalecik ilçe merkezinde eski ve yeni olmak üzere iki tip yerleşim alanı bulunmaktadır. İlçenin kuzeyi gelişmekte olan yeni yerleşim alanında planlı ve çok katlı yapılaşma görülmektedir. Eski kent dokusu ise Kalecik Kalesi'nin çevresinde, Ahikemal-Şenyurt Mahallesi ve Halilağa-Tabakhane Mahallesi'nde varlığını korumaktadır. Bu mahalleler konut yerleşimlerinin düzenli olmadığı, genellikle tek ya da iki katlı yapıların bulunduğu alanlardır (Çınar, 2020).

Çalışmada ilçe merkezini bir aks gibi ikiye bölen Hüseyin Sağırkaya Bulvarı ve İstasyon Caddesine komşu üç park incelenmiştir. Bu parklar kuzeyden güneye doğru Şehitler Parkı (P1), Osman Arslan Parkı (P2) ve Atatürk Park1 (P3) olup konumları Şekil 1'de verilmiştir.
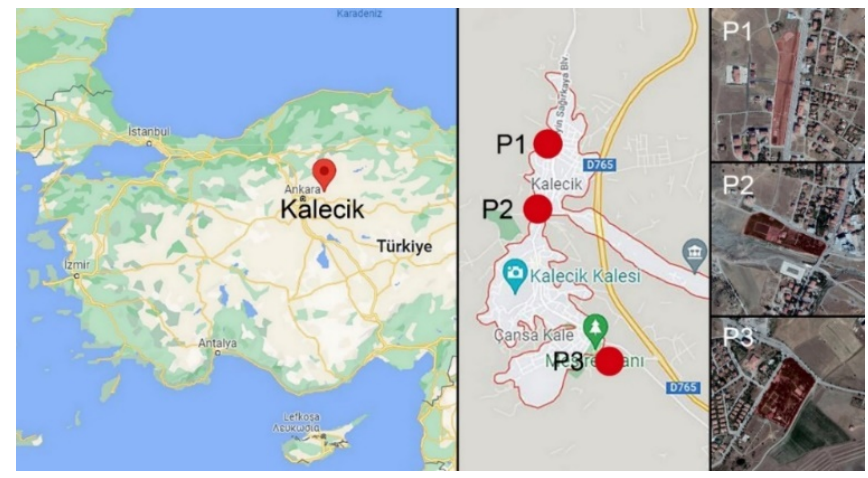

Şekil 1. Çalışmanın yürütüldüğü Kalecik ilçesi ve parkların konumu (Google Earth, 2021 ve Google Maps, 2021 verilerinden uyarlanmıştır.) 


\section{YÖNTEM}

Çalışmanın yöntemi ana ve alt kriterlerin belirlenmesi, Simos prosedürü ile ağırlıkların tayin edilmesi, uygunluk puanlarının verilerek her bir alt kriter için SLDI değerlerinin hesaplanması olmak üzere üç temel aşamadan oluşmaktadır. Bu aşamalar alt bölümler halinde verilmiştir.

\section{Kriter Seçimi}

Birinci aşama değerlendirme kriterlerinin belirlenmesidir. SITES Derecelendirme Sisteminin alan tasarımı başlığ altındaki toprak ve vejetasyon (7), materyal seçimi (7), su (5), insan sağlığı ve refahı (11) olmak üzere dört ana kritere (Main criteria, MC) ait alt kriterler çalışmanın amacına ve çalışma alanına uyarlanarak toplam 30 alt kriter (Sub-criteria, SC) değerlendirmeye alınmıştır (Tablo 1).

Tablo 1. Ana ve alt kriterler

\begin{tabular}{|c|c|c|c|}
\hline $\begin{array}{l}\text { Ana } \\
\text { kriterler }\end{array}$ & Alt kriterler & $\begin{array}{l}\text { Ana } \\
\text { kriterler }\end{array}$ & Alt kriterler \\
\hline $\begin{array}{l}\mathrm{MC}_{1} \\
\text { Toprak ve } \\
\text { vejetasyon }\end{array}$ & $\begin{array}{l}\mathrm{SC}_{1} \text { : Toprak yönetimi } \\
\mathrm{SC}_{2} \text { : Sağllkl1 toprakları ve bitkileri koruma } \\
\mathrm{SC}_{3} \text { : İstilac1 bitkilerin kontrolü } \\
\mathrm{SC}_{4} \text { : Uygun bitki kullanımı } \\
\mathrm{SC}_{5} \text { : Yerel türleri koruma ve kullanma } \\
\mathrm{SC}_{6} \text { : Biyokütlenin optimizasyonu } \\
\mathrm{SC}_{7} \text { : Is1 adas1 etkisini azaltma }\end{array}$ & $\begin{array}{l}\mathrm{MC}_{2} \\
\text { Materyal } \\
\text { seçimi }\end{array}$ & $\begin{array}{l}\text { SC8: Tehdit altındaki türlerden üretilen } \\
\text { ahşap materyal kullanımını azaltma } \\
\mathrm{SC}_{9} \text { : Mevcut yapı ve kaplamaları } \\
\text { değerlendirme } \\
\mathrm{SC}_{10} \text { : Uyarlanabilir ve demonte } \\
\text { konstrüksiyon } \\
\mathrm{SC}_{11} \text { : Geri dönüştürülmüş materyal } \\
\text { kullanımı } \\
\mathrm{SC}_{12} \text { : Yerel malzeme kullanımı } \\
\mathrm{SC}_{13} \text { : Az veya güvenli kimyasal madde } \\
\text { kullanımı } \\
\mathrm{SC}_{14} \text { : Sürdürülebilir materyal kullanımı }\end{array}$ \\
\hline $\begin{array}{l}\mathrm{MC}_{3} \\
\mathrm{Su}\end{array}$ & $\begin{array}{l}\mathrm{SC}_{15} \text { : Yağı̧ıı yerinde yönetimi } \\
\mathrm{SC}_{16} \text { : Sulama suyu ihtiyacını azaltma } \\
\mathrm{SC}_{17} \text { : Yağmur suyundan faydalanma } \\
\mathrm{SC}_{18} \text { : Randımanlı bir sulama sistemi } \\
\mathrm{SC}_{19} \text { : Etkin bir drenaj sistemi }\end{array}$ & $\begin{array}{l}\mathrm{MC}_{4} \\
\text { İnsan sağllğg } 1 \\
\text { ve refah1 }\end{array}$ & $\begin{array}{l}\mathrm{SC}_{20} \text { : Kültürel ve tarihi özellikleri koruma } \\
\text { ve içerme } \\
\mathrm{SC}_{21} \text { : Erişilebilirlik } \\
\mathrm{SC}_{22} \text { : Güvenlik } \\
\mathrm{SC}_{23} \text { : Kolay anlaş1lır sirkülasyon } \\
\mathrm{SC}_{24} \text { : Yerel halka sosyal fayda sağlama } \\
\mathrm{SC}_{25} \text { : Zihinsel yenilenmeye katk1 sağlama } \\
\mathrm{SC}_{26} \text { : Fiziksel aktivite olanakları sunma } \\
\mathrm{SC}_{27} \text { : Toplumsal iletişimi destekleme } \\
\mathrm{SC}_{28} \text { : Iş1k kirliliğini azaltma } \\
\mathrm{SC}_{29} \text { : Dumansız hava sahasi sunma } \\
\mathrm{SC}_{30} \text { : Yerel ekonomiyi destekleme }\end{array}$ \\
\hline
\end{tabular}

\section{Simos Prosedürü}

İkinci aşama $\mathrm{MC}$ ve SC'lerin kendi aralarında sürdürülebilir tasarım bakımından eşit etkiye sahip olmamasından hareketle, ağırlık vermede kullanılacak Çok Kriterli Karar Verme (ÇKKV) tekniğinin seçilmesidir. ÇKKV teknikleri karar vericiler için güvenilir araçlardır ve bu çalışmada Jean Simos tarafından 1990 yllında geliştirilen teknik kullanılmıştır. Simos prosedürü olarak bilinen teknik, bir kriter grubunun farklı üyelerini sayısal değerler tayin ederek hiyerarşik olarak sıralamayı sağlar. Teknik birçok alanda araştırmacılar tarafından kendi tercihlerini ortaya koymak veya konuyla ilgili uzmanların fikirlerini derlemek amacıyla kullanılmıştır (Aşılıoğlu, 2021; Aşılığglu ve Memlük, 2017; de Sousa Pereira ve Morais, 2020; Górecka, 2016; Govindan vd., 2017; Marzouk vd., 2014; Merad vd., 2013; Ribas ve da Silva Rocha, 2015; Wilkens ve Schmuck, 2012). Daha sonra önemli bir bilginin eksik olması ve yanlışlıkla kriterlere eşit ağırlık tayin edilmesi gibi sebeplerle Figueira ve Roy (2002) tarafından revize edilmiştir. Simos prosedürü bir kart oyunu yöntemidir. Ana kriterlere ve alt kriterlere ağırlık tayin etmek için karar vericilere üzerinde kriterlerin yazılı olduğu bir dizi kart ve beyaz kartlar verilmiştir. 
Onlardan bu kartları sürdürülebilir peyzaj tasarımı bakımından en az önemliden en çok önemliye doğru sıralamaları, ardışık iki kriter arasındaki önem farkını artırmak için beyaz kartları kullanmaları ve eşit öneme sahip olduğunu düşündükleri kartları alt gruplar halinde birleştirmeleri istenmiştir. Bu süreç önce ana kriterler için sonra her bir ana kriterin alt kriterleri için olmak üzere beş kez uygulanmıştır (Şekil 2). Tablo 2'de ana kriter ağırlıkları, Tablo 3'de ise alt kriter ağırlıkları hesaplanmış ve formülleriyle birlikte verilmiştir.

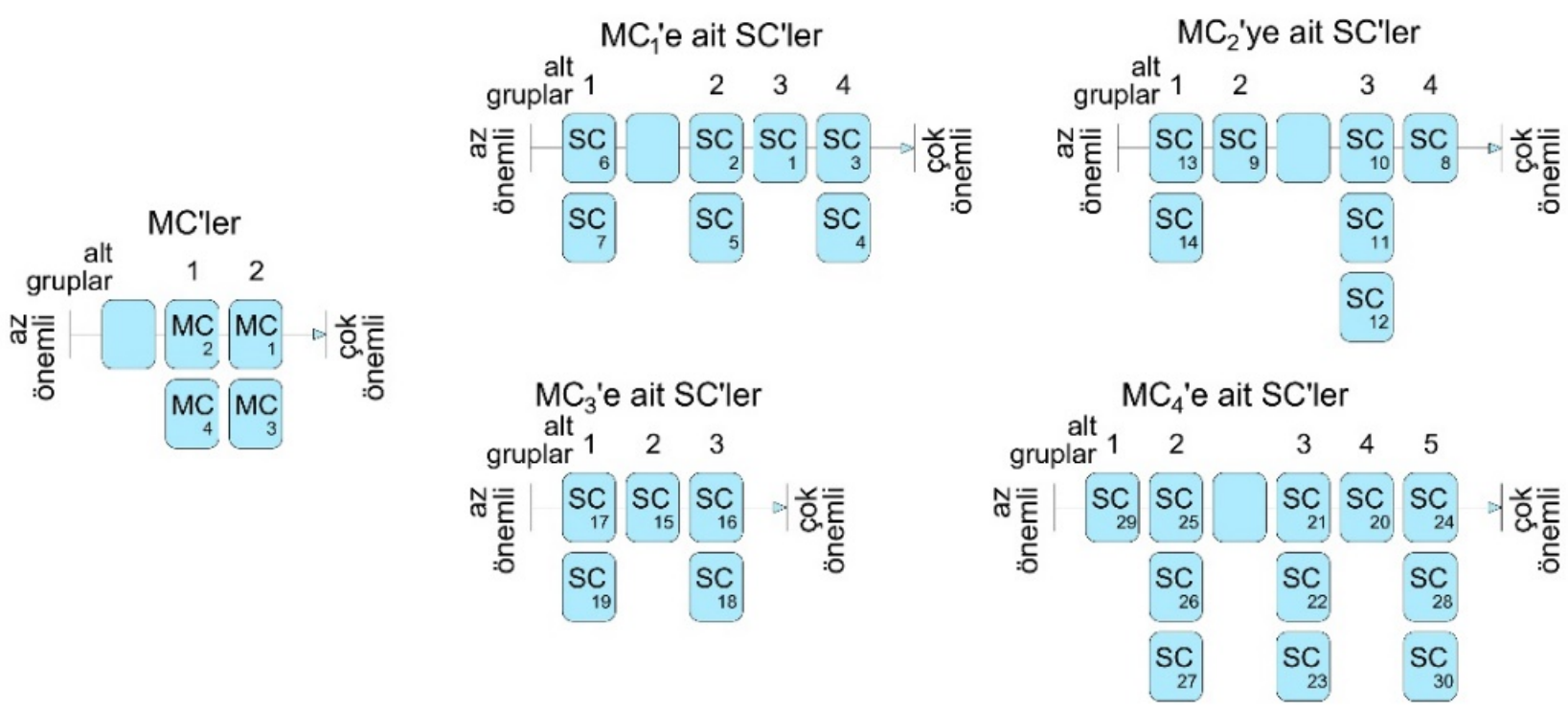

Şekil 2. Simos’un kart oyunu yöntemi (Aş1lığglu, 2021; Shanian vd., 2008)

Tablo 2. MC ağırlıklarının hesaplanması Simos prosedürü ile hesaplanması

\begin{tabular}{lllll}
\hline MC alt grupları & Kart sayısı, $n$ & Kart sırası, $p$ & Ağırlıklar, $W_{f}=p / n$ & $\begin{array}{l}\text { Normalleştirilmiş } \\
\text { ağırlıklar, } W_{m}=W_{f} / p_{t}\end{array}$ \\
\hline Beyaz & 1 & $(1)$ & - & - \\
$\mathrm{MC}_{2}, \mathrm{MC}_{4}$ & 2 & 2,3 & $(2+3) / 2=2,50$ & $0,1786(\mathrm{x} 2)$ \\
$\mathrm{MC}_{1}, \mathrm{MC}_{3}$ & 2 & 4,5 & $(4+5) / 2=4,50$ & $0,3214(\mathrm{x} 2)$ \\
\hline Toplam & & $p_{t}=14$ & & 1,0000 \\
\hline
\end{tabular}


Tablo 3. SC ağırlıklarının hesaplanması Simos prosedürü ile hesaplanması

\begin{tabular}{|c|c|c|c|c|c|}
\hline $\mathrm{MC}$ & SC alt grupları & $\begin{array}{l}\text { Kart sayisı, } \\
n\end{array}$ & Kart sirasi, $p$ & Ağırlıklar, $W_{f}=p / n$ & $\begin{array}{l}\text { Normalleştirilmiş } \\
\text { ağırlıklar, } W_{s}=W_{f} / p_{t}\end{array}$ \\
\hline \multirow{6}{*}{$\mathrm{MC}_{1}$} & $\mathrm{SC}_{6}, \mathrm{SC}_{7}$ & 2 & 1,2 & $(1+2) / 2=1,5$ & $0,0455(\mathrm{x} 2)$ \\
\hline & Beyaz & 1 & (3) & - & - \\
\hline & $\mathrm{SC}_{2}, \mathrm{SC}_{5}$ & 2 & 4,5 & $(4+5) / 2=4,5$ & $0,1364(x 2)$ \\
\hline & $\mathrm{SC}_{1}$ & 1 & 6 & 6.00 & 0,1818 \\
\hline & $\mathrm{SC}_{3}, \mathrm{SC}_{4}$ & 2 & 7,8 & $(7+8) / 2=7,5$ & $0,2273(\mathrm{x} 2)$ \\
\hline & Toplam & & $p_{t}=33$ & & 1,0002 \\
\hline \multirow{6}{*}{$\mathrm{MC}_{2}$} & $\mathrm{SC}_{13}, \mathrm{SC}_{14}$ & 2 & 1,2 & $(1+2) / 2=1,5$ & $0,0469(\mathrm{x} 2)$ \\
\hline & $\mathrm{SC}_{9}$ & 1 & 3 & 3,0 & 0,0938 \\
\hline & Beyaz & 1 & (4) & - & - \\
\hline & $\mathrm{SC}_{10}, \mathrm{SC}_{11}, \mathrm{SC}_{12}$ & 3 & $5,6,7$ & $(5+6+7) / 3=6,0$ & $0,1875(x 3)$ \\
\hline & $\mathrm{SC}_{8}$ & 1 & 8 & 8,0 & 0,2500 \\
\hline & Toplam & & $p_{t}=32$ & & 1,0001 \\
\hline \multirow{4}{*}{$\mathrm{MC}_{3}$} & $\mathrm{SC}_{17}, \mathrm{SC}_{19}$ & 2 & 1,2 & $(1+2) / 2=1,5$ & $0,1000(\mathrm{x} 2)$ \\
\hline & $\mathrm{SC}_{15}$ & 1 & 3 & 3.0 & 0,2000 \\
\hline & $\mathrm{SC}_{16}, \mathrm{SC}_{18}$ & 2 & 4,5 & $(4+5) / 2=4,5$ & $0,3000(x 2)$ \\
\hline & Toplam & & $p_{t}=15$ & & 1,0000 \\
\hline \multirow{7}{*}{$\mathrm{MC}_{4}$} & $\mathrm{SC}_{29}$ & 1 & 1 & 1.0 & 0,0137 \\
\hline & $\mathrm{SC}_{25}, \mathrm{SC}_{26}, \mathrm{SC}_{27}$ & 2 & $2,3,4$ & $(2+3+4) / 3=3,0$ & $0,0411(x 3)$ \\
\hline & Beyaz & 1 & (5) & - & - \\
\hline & $\mathrm{SC}_{21}, \mathrm{SC}_{22}, \mathrm{SC}_{23}$ & 3 & $6,7,8$ & $(6+7+8) / 3=7,0$ & $0,0959(x 3)$ \\
\hline & $\mathrm{SC}_{20}$ & 1 & 9 & 9,0 & 0,1232 \\
\hline & $\mathrm{SC}_{24}, \mathrm{SC}_{28}, \mathrm{SC}_{30}$ & 3 & $10,11,12$ & $(10+11+12) / 3=11,0$ & $0,1507(x 3)$ \\
\hline & Toplam & & $p_{t}=73$ & & 1,0000 \\
\hline
\end{tabular}

Tablo 2 incelendiğince 0,3214 ile $\mathrm{MC}_{1}$ Toprak ve vejetasyon ve $\mathrm{MC}_{3} \mathrm{Su}$ ana kriterlerinin en yüksek ağırlığı aldıkları görülmektedir. $\mathrm{MC}_{2}$ Materyal seçimi ve $\mathrm{MC}_{4}$ İnsan sağlığı ve refahı ana kriterlerinin ağırlıkları ise 0,1786 olarak hesaplanmıştır. Tablo 3'te $\mathrm{MC}_{1}$ 'in alt kriterlerinin ağırlıkları 0,2273 ile $\mathrm{SC}_{3}$ İstilacı bitkilerin kontrolü ve $\mathrm{SC}_{4}$ Uygun bitki kullanımı başta olmak üzere sırasıyla, 0,1818 $\mathrm{SC}_{1}$ Toprak yönetimi, 0,1364 $\mathrm{SC}_{2}$ Sağlıklı toprakları ve bitkileri koruma ve $\mathrm{SC}_{5}$ Yerel türleri koruma ve kullanma, $0,0455 \mathrm{SC}_{6}$ Biyokütlenin optimizasyonu ve $\mathrm{SC}_{7}$ Is1 adas1 etkisini azaltma olarak belirlenmiştir. $\mathrm{MC}_{2}$ 'nin alt kriterlerine bakıldığında 0,2500 ile $\mathrm{SC}_{8}$ Tehdit altındaki türlerden üretilen ahşap materyal kullanmanın en etkili alt kriter olduğu görülmektedir. Bunu 0,1875 ile $\mathrm{SC}_{10}$ Uyarlanabilir ve demonte konstrüksiyon, $\mathrm{SC}_{11}$ Geri dönüştürülmüş materyal kullanımı ve $\mathrm{SC}_{12}$ Yerel malzeme kullanımı, 0,0938 ile $\mathrm{SC}_{9}$ Mevcut yapı ve kaplamaları değerlendirme, 0,0469 ile $\mathrm{SC}_{13} \mathrm{Az}$ veya güvenli kimyasal madde kullanımı ve $\mathrm{SC}_{14}$ Sürdürülebilir materyal kullanımı izlemektedir. $\mathrm{MC}_{3}$ 'ün ağırlık sıralaması ise $0,3000 \mathrm{SC}_{16}$ Sulama suyu ihtiyacını azaltma ve $\mathrm{SC}_{18}$ Randımanlı sulama sistemi, 0,2000 $\mathrm{SC}_{15}$ Yağışın yerinde yönetimi, 0,1000 $\mathrm{SC}_{17}$ Yağmur suyundan faydalanma ve $\mathrm{SC}_{19}$ Etkin drenaj sistemi şeklindedir. $\mathrm{MC}_{4}$ 'ün alt kriterlerinde 0,1507 ile $\mathrm{SC}_{24}$ Yerel halka sosyal fayda sağlama, $\mathrm{SC}_{28}$ Işsk kirliliğini azaltma ve $\mathrm{SC}_{30}$ Yerel ekonomiyi destekleme alt kriterleri başta gelmektedir. Bunu 0,1232 ile $\mathrm{SC}_{20}$ Kültürel ve tarihi özellikleri koruma ve içerme, 0,0959 ile $\mathrm{SC}_{21}$ Erişilebilirlik, $\mathrm{SC}_{22}$ Güvenlik ve $\mathrm{SC}_{23}$ Kolay anlaş1lır sirkülasyon, 0,0411 ile $\mathrm{SC}_{25}$ Zihinsel yenilenmeye katkı sağlama, $\mathrm{SC}_{26}$ Fiziksel aktivite olanakları sunma ve $\mathrm{SC}_{27}$ Toplumsal iletişimi destekleme, 0,0137 ile $\mathrm{SC}_{29}$ Dumansiz hava sahası sunma takip etmektedir.

\section{Sürdürülebilir Peyzaj Tasarımı Katsayısı (SLDI)}

Yöntemin üçüncü aşaması, niteliklerden yola çıkarak parkların sürdürülebilir peyzaj tasarımına uygunluk düzeylerini belirleyen nicel değerlendirmenin sonucu olan SLDI'nın hesaplanmasıdır. SITES (2014) rehberinde alan tasarımı başlığı altında bulunan toprak ve vejetasyon, materyal seçimi, su ve insan sağlığı ve refahı olmak üzere dört ana kriter ve bunların kapsadığı 30 alt kriter sürdürülebilir tasarımın ölçülebilir boyutlarını oluşturmuştur. Simos prosedürü ile 
ağırlıklar belirlendikten sonra, 5'li Likert ölçeği kullanılarak uygunluk puanları verilmiş ve bu iki değer ile SLDI hesaplanmıştır. Tablo 4 'te tüm alt kriterler, ağırlıklar, uygunluk puanları ve P1 Şehitler Parkı, P2 Osman Arslan Parkı, P3 Atatürk Parkı olmak üzere tüm parklar için hesaplanan SLDI değerleri formülleriyle birlikte verilmiştir. Katsayı değerlerinin tablolar, sayılar ve puanlarla ifade edilmesi kolay anlaşılma ve karşılaştırma açısından yetersiz ve karmaşıktır (Mehta, 2014). Bu nedenle bulgular diyagramlar halinde sunulmuş ve yorumlanmıştır.

Tablo 4. SLDI değerlerinin hesaplanması

\begin{tabular}{|c|c|c|c|c|c|c|c|c|c|c|c|c|c|}
\hline \multirow[t]{2}{*}{$\mathrm{MC}$} & \multirow[t]{2}{*}{$W_{m}$} & \multirow[t]{2}{*}{$\mathrm{SC}$} & \multirow[t]{2}{*}{$W_{s}$} & \multirow{2}{*}{$\begin{array}{c}\text { Toplam } \\
\text { ağırlıklar } \\
W=W_{m} x W_{s}\end{array}$} & \multicolumn{3}{|c|}{$\begin{array}{c}\text { Uygunluk puanlar1 } \\
(1-5) \\
V\end{array}$} & \multicolumn{3}{|c|}{$\begin{array}{l}\text { SLDI } \\
W x V\end{array}$} & \multicolumn{3}{|c|}{$\mathrm{SLDI}_{\text {ort }}$} \\
\hline & & & & & P1 & $\overline{\mathrm{P} 2}$ & P3 & P1 & P2 & P3 & P1 & P2 & P3 \\
\hline \multirow{7}{*}{$\mathrm{MC}_{1}$} & \multirow{7}{*}{0,3214} & $\mathrm{SC}_{1}$ & 0,1818 & 0,0584 & 3 & 3 & 1 & 0,1753 & 0,1753 & 0,0584 & \multirow{7}{*}{0,1106} & \multirow{7}{*}{0,1252} & \multirow{7}{*}{0,1294} \\
\hline & & $\mathrm{SC}_{2}$ & 0,1364 & 0,0438 & 2 & 5 & 5 & 0,0877 & 0,2192 & 0,2192 & & & \\
\hline & & $\mathrm{SC}_{3}$ & 0,2273 & 0,0731 & 1 & 1 & 1 & 0,0731 & 0,0731 & 0,0731 & & & \\
\hline & & $\mathrm{SC}_{4}$ & 0,2273 & 0,0731 & 2 & 2 & 4 & 0,1461 & 0,1461 & 0,2922 & & & \\
\hline & & $\mathrm{SC}_{5}$ & 0,1364 & 0,0438 & 5 & 4 & 4 & 0,2192 & 0,1754 & 0,1754 & & & \\
\hline & & $\mathrm{SC}_{6}$ & 0,0455 & 0,0146 & 1 & 1 & 1 & 0,0146 & 0,0146 & 0,0146 & & & \\
\hline & & $\mathrm{SC}_{7}$ & 0,0455 & 0,0146 & 4 & 5 & 5 & 0,0585 & 0,0731 & 0,0731 & & & \\
\hline \multirow{7}{*}{$\mathrm{MC}_{2}$} & \multirow{7}{*}{0,1786} & $\mathrm{SC}_{8}$ & 0,2500 & 0,0447 & 4 & 5 & 5 & 0,1786 & 0,2233 & 0,2233 & \multirow{7}{*}{0,0734} & \multirow{7}{*}{0,0726} & \multirow{7}{*}{0,0750} \\
\hline & & $\mathrm{SC}_{9}$ & 0,0938 & 0,0168 & 3 & 2 & 1 & 0,0503 & 0,0335 & 0,0168 & & & \\
\hline & & $\mathrm{SC}_{10}$ & 0,1875 & 0,0335 & 2 & 1 & 1 & 0,0670 & 0,0335 & 0,0335 & & & \\
\hline & & $\mathrm{SC}_{11}$ & 0,1875 & 0,0335 & 1 & 1 & 2 & 0,0335 & 0,0335 & 0,0670 & & & \\
\hline & & $\mathrm{SC}_{12}$ & 0,1875 & 0,0335 & 4 & 4 & 4 & 0,1340 & 0,1340 & 0,1340 & & & \\
\hline & & $\mathrm{SC}_{13}$ & 0,0469 & 0,0084 & 3 & 3 & 3 & 0,0251 & 0,0251 & 0,0251 & & & \\
\hline & & $\mathrm{SC}_{14}$ & 0,0469 & 0,0084 & 3 & 3 & 3 & 0,0251 & 0,0251 & 0,0251 & & & \\
\hline \multirow{5}{*}{$\mathrm{MC}_{3}$} & \multirow{5}{*}{0,3214} & $\mathrm{SC}_{15}$ & 0,2000 & 0,0643 & 3 & 1 & 2 & 0,1928 & 0,0643 & 0,1286 & \multirow{5}{*}{0,1607} & \multirow{5}{*}{0,0900} & \multirow{5}{*}{0,0771} \\
\hline & & $\mathrm{SC}_{16}$ & 0,3000 & 0,0964 & 2 & 1 & 1 & 0,1928 & 0,0964 & 0,0964 & & & \\
\hline & & $\mathrm{SC}_{17}$ & 0,1000 & 0,0321 & 1 & 1 & 1 & 0,0321 & 0,0321 & 0,0321 & & & \\
\hline & & $\mathrm{SC}_{18}$ & 0,3000 & 0,0964 & 3 & 2 & 1 & 0,2893 & 0,1928 & 0,0964 & & & \\
\hline & & $\mathrm{SC}_{19}$ & 0,1000 & 0,0321 & 3 & 2 & 1 & 0,0964 & 0,0643 & 0,0321 & & & \\
\hline \multirow{11}{*}{$\mathrm{MC}_{4}$} & \multirow{11}{*}{0,1786} & $\mathrm{SC}_{20}$ & 0,1232 & 0,0220 & 1 & 2 & 3 & 0,0220 & 0,0440 & 0,0660 & \multirow{11}{*}{0,0423} & & \\
\hline & & $\mathrm{SC}_{21}$ & 0,0959 & 0,0171 & 3 & 5 & 3 & 0,0514 & 0,0856 & 0,0514 & & & \\
\hline & & $\mathrm{SC}_{22}$ & 0,0959 & 0,0171 & 4 & 1 & 5 & 0,0685 & 0,0171 & 0,0856 & & & \\
\hline & & $\mathrm{SC}_{23}$ & 0,0959 & 0,0171 & 5 & 2 & 4 & 0,0856 & 0,0343 & 0,0685 & & & \\
\hline & & $\mathrm{SC}_{24}$ & 0,1507 & 0,0269 & 2 & 5 & 5 & 0,0538 & 0,1346 & 0,1346 & & & \\
\hline & & $\mathrm{SC}_{25}$ & 0,0411 & 0,0073 & 2 & 4 & 4 & 0,0147 & 0,0294 & 0,0294 & & 0,0583 & 0,0672 \\
\hline & & $\mathrm{SC}_{26}$ & 0,0411 & 0,0073 & 5 & 5 & 4 & 0,0367 & 0,0367 & 0,0294 & & & \\
\hline & & $\mathrm{SC}_{27}$ & 0,0411 & 0,0073 & 3 & 5 & 4 & 0,0220 & 0,0367 & 0,0294 & & & \\
\hline & & $\mathrm{SC}_{28}$ & 0,1507 & 0,0269 & 2 & 4 & 5 & 0,0538 & 0,1077 & 0,1346 & & & \\
\hline & & $\mathrm{SC}_{29}$ & 0,0137 & 0,0024 & 1 & 3 & 1 & 0,0024 & 0,0073 & 0,0024 & & & \\
\hline & & $\mathrm{SC}_{30}$ & 0,1507 & 0,0269 & 2 & 4 & 4 & 0,0538 & 0,1077 & 0,1077 & & & \\
\hline
\end{tabular}

\section{BULGULAR ve TARTIŞMA:}

\section{P1 Şehitler Parkı}

Şehitler Parkı Kalecik ilçe merkezinin kuzey girişinde yer alan, yaklaşık $24.209 \mathrm{~m}^{2}$ büyüklüğünde bir parktır. Yapımı 2017 yılında tamamlanmış olup, ilçenin en yeni parkıdır. Parkta diğerlerinden farklı olarak bir amfi ve civardan gelen yüzey akışını toplayan doğal dere bulunmaktadır. Diğer peyzaj ögeleri yaya yolları, oturma birimleri, donatı elemanları, plastik ögeler, köprüler, hizmet binaları, spor sahaları, WC, çevre duvarı, güvenlik kameraları, çocuk oyun alanları, fitness alanları, koşu parkuru, sulama sistemi, drenaj elemanları ve bitkisel alanlardır (Şekil 3). 


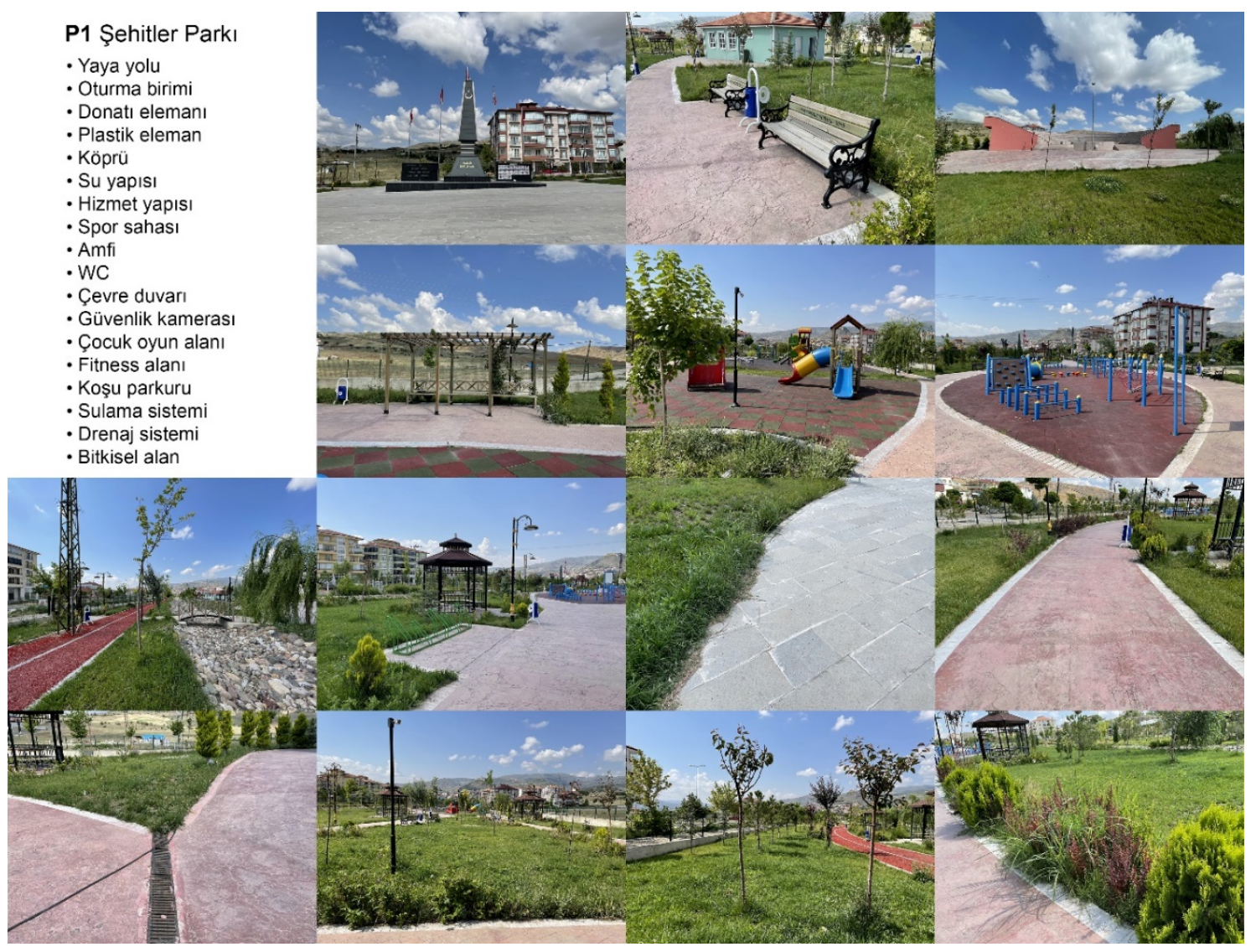

Şekil 3. P1 Şehitler Parkı peyzaj ögeleri listesi ve alandan görünümler

Şehitler Parkı için hesaplanan SLDI değerlerine ilişkin diyagramlar Şekil 4'te görülmektedir. Kolay anlaşılması ve

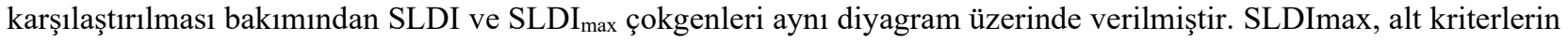
normalleştirilmiş ağırlıkları ile, Likert ölçeğindeki maksimum uygunluk puanı olan 5'in çarpımını, yani tüm alt kriterlerin tam puan aldığının varsayıldığ 1 düzeyi ifade etmektedir. Diyagramdan $\mathrm{MC}_{1}$ Toprak ve vejetasyon incelendiğinde en yüksek SLDI'nın $\mathrm{SC}_{5}$ Yerel türleri koruma ve kullanma alt kriterine ait olduğu görülmektedir. Bunu sırasıyla $\mathrm{SC}_{1}$ Toprak yönetimi, $\mathrm{SC}_{4}$ Uygun bitki kullanımı, $\mathrm{SC}_{2}$ Sağlıklı toprakları ve bitkileri koruma, $\mathrm{SC}_{3}$ İstilac1 bitkilerin kontrolü, $\mathrm{SC}_{7}$ Isı adası etkisini azaltma izlemektedir. $\mathrm{SC}_{6}$ Biyokütlenin optimizasyonu ise en düşük SLDI değerine sahip alt kriterdir. $\mathrm{MC}_{2}$ Materyal seçiminde ise $\mathrm{SC}_{8}$ Tehdit altındaki türlerden üretilen ahşap materyal kullanımını azaltma alt kriteri en yüksek, $\mathrm{SC}_{13} \mathrm{Az}$ veya güvenli kimyasal madde kullanımı ile $\mathrm{SC}_{14}$ Sürdürülebilir materyal kullanımı alt kriterleri en düşük SLDI değerini almıştır. Diğer alt kriterler yüksekten düşüğe doğru, $\mathrm{SC}_{12}$ Yerel malzeme kullanımı, $\mathrm{SC}_{10}$ Uyarlanabilir ve demonte konstrüksiyon, $\mathrm{SC}_{9}$ Mevcut yapı ve kaplamaları değerlendirme, $\mathrm{SC}_{11}$ Geri dönüştürülmüş materyal kullanımı şeklinde sıralanmıştır. $\mathrm{MC}_{3} \mathrm{Su}$ diyagramında en yüksek SLDI değerini almış olan alt kriter $\mathrm{SC}_{18}$ Randımanlı sulama sistemidir ve aynı zamanda tüm alt kriterler içinde de en yüksek değeri almıştır. Bunu sırasıyla eşit değerlerle $\mathrm{SC}_{15}$ Yağışın yerinde yönetimi ve $\mathrm{SC}_{16}$ Sulama suyu ihtiyacını azaltma, $\mathrm{SC}_{19}$ Etkin drenaj sistemi izlemektedir. En düşük SLDI'ya sahip alt kriter $\mathrm{SC}_{17}$ Yağmur suyundan faydalanmadır. $\mathrm{MC}_{4}$ İnsan sağlığı ve refahı diyagramı incelendiğinde $\mathrm{SC}_{23}$ Kolay anlaşılır sirkülasyon alt kriterinin ilk sırada yer aldığ görülmektedir. Diğerleri ise yüksekten düşüğe doğru $\mathrm{SC}_{22}$ Güvenlik, $\mathrm{SC}_{24}$ Yerel halka sosyal fayda sağlama, $\mathrm{SC}_{28}$ Işık kirliliğini azaltma, $\mathrm{SC}_{30}$ Yerel ekonomiyi destekleme, $\mathrm{SC}_{21}$ Erişilebilirlik, $\mathrm{SC}_{26}$ Fiziksel aktivite olanakları sunma, $\mathrm{SC}_{20}$ Kültürel ve tarihi özellikleri koruma ve içerme, $\mathrm{SC}_{27}$ Toplumsal iletişimi destekleme, $\mathrm{SC}_{25}$ Zihinsel yenilenmeye katk1 sağlama şeklinde sıralanmıştır. En düşük SLDI değerine sahip alt kriter olan $\mathrm{SC}_{29}$ Dumansız hava sahası sunma aynı zamanda tüm alt kriterler arasında da en düşüktür. 


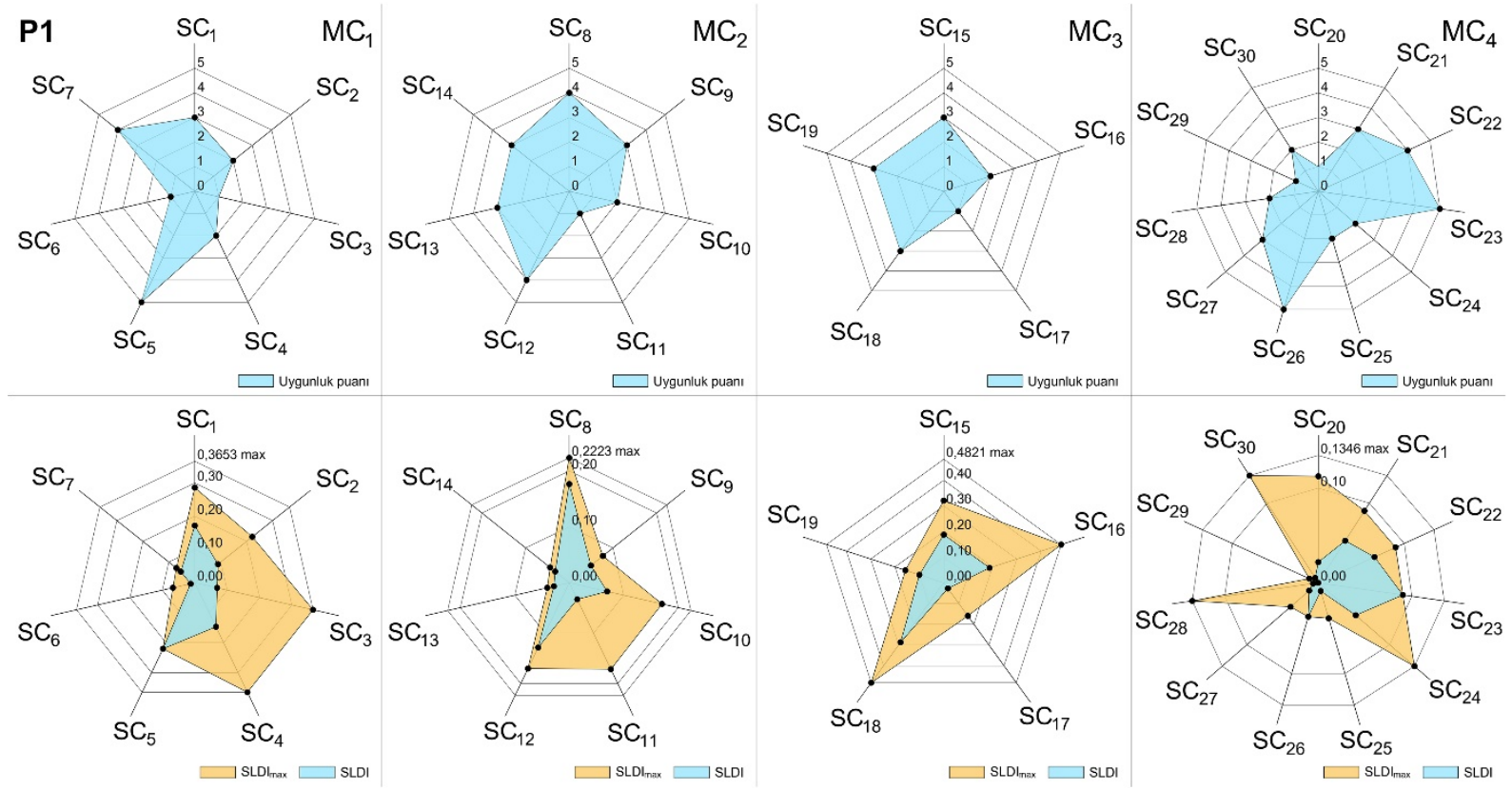

Şekil 4. P1 Şehitler Parkı SLDI diyagramları

\section{P2 Osman Arslan Parkı}

Diğerlerine göre daha merkezi bir konuma sahip olan Osman Arslan Park1 $23.195 \mathrm{~m}^{2}$ lik bir alana sahiptir ve 2006 yılında yapılmıştır. 2015 yılında ilave edilen sosyal tesis ve spor sahaları ile kullanıcılara daha fazla olanak sunar hale gelmiştir. Parktaki peyzaj ögeleri yaya yolları, oturma birimleri, donatı elemanları, köprüler, sosyal tesis ve hizmet binaları, spor sahaları, otopark, WC, çocuk oyun alanları, fitness alanları, sulama sistemi ve bitkisel alanlardır (Şekil 5).

Osman Arslan Parkı için hesaplanan SLDI değerlerine ilişkin diyagramlar Şekil 6'da görülmektedir. Şekilde $\mathrm{MC}_{1}$ Toprak ve vejetasyon diyagramı incelendiğinde en yüksek SLDI'nın $\mathrm{SC}_{2}$ Sağlıklı toprakları ve bitkileri koruma alt kriterine ait olduğu görülmektedir. Bunu sırasıyla $\mathrm{SC}_{5}$ Yerel türleri koruma ve kullanma, $\mathrm{SC}_{1}$ toprak yönetimi, $\mathrm{SC}_{4}$ Uygun bitki kullanımı, $\mathrm{SC}_{3}$ İstilacı bitkilerin kontrolü ve $\mathrm{SC}_{7}$ Is1 adası etkisini azaltma izlemektedir. $\mathrm{SC}_{6}$ Biyokütlenin optimizasyonu ise en düşük SLDI değerine sahip alt kriterdir. $\mathrm{MC}_{2}$ Materyal seçiminde ise $\mathrm{SC}_{8}$ Tehdit altındaki türlerden üretilen ahşap materyal kullanımını azaltma alt kriteri gerek grup içerisinde gerekse tüm alt kriterler içerisinde en yüksek, $\mathrm{SC}_{13} \mathrm{Az}$ veya güvenli kimyasal madde kullanımı ile $\mathrm{SC}_{14}$ Sürdürülebilir materyal kullanımı ise en düşük SLDI değerlerini almıştır. $\mathrm{SC}_{12}$ Yerel malzeme kullanımı ikinci sırada, $\mathrm{SC}_{9}$ Mevcut yapı ve kaplamaları değerlendirme, $\mathrm{SC}_{10}$ Uyarlanabilir ve demonte konstrüksiyon ve $\mathrm{SC}_{11}$ Geri dönüştürülmüş materyal kullanımı ise eşit SLDI değerleriyle üçüncü sırada yer almıştır. $\mathrm{MC}_{3}$ Su diyagramında en yüksek SLDI değerini almış olan alt kriter $\mathrm{SC}_{18}$ Randımanlı sulama sistemidir. Bunu sırasıyla $\mathrm{SC}_{16}$ Sulama suyu ihtiyacını azaltma, eşit değerlerle $\mathrm{SC}_{15}$ Yağışın yerinde yönetimi ve $\mathrm{SC}_{19}$ Etkin drenaj sistemi izlemektedir. En düşük SLDI'ya sahip alt kriter $\mathrm{SC}_{17}$ Yağmur suyundan faydalanmadır. $\mathrm{MC}_{4}$ İnsan sağlığı ve refahı diyagramı incelendiğinde $\mathrm{SC}_{24}$ Yerel halka sosyal fayda sağlama alt kriterinin ilk sırada yer aldığı görülmektedir. Diğerleri ise yüksekten düşüğe doğru eşit değerlerle $\mathrm{SC}_{28}$ Iş̧ı kirliliğini azaltma ve $\mathrm{SC}_{30}$ Yerel ekonomiyi destekleme, $\mathrm{SC}_{21}$ Erişilebilirlik, $\mathrm{SC}_{20}$ Kültürel ve tarihi özellikleri koruma ve içerme, eşit değerlerle $\mathrm{SC}_{26}$ Fiziksel aktivite olanakları sunma ve $\mathrm{SC}_{27}$ Toplumsal iletişimi destekleme, $\mathrm{SC}_{23}$ Kolay anlaşı1ır sirkülasyon, $\mathrm{SC}_{25}$ Zihinsel yenilenmeye katkı sağlama, $\mathrm{SC}_{22}$ Güvenlik şeklinde sıralanmıştır. En düşük SLDI değerine sahip alt kriter olan $\mathrm{SC}_{29}$ Dumansız hava sahası sunma aynı zamanda tüm alt kriterler arasında da en düşüktür. 


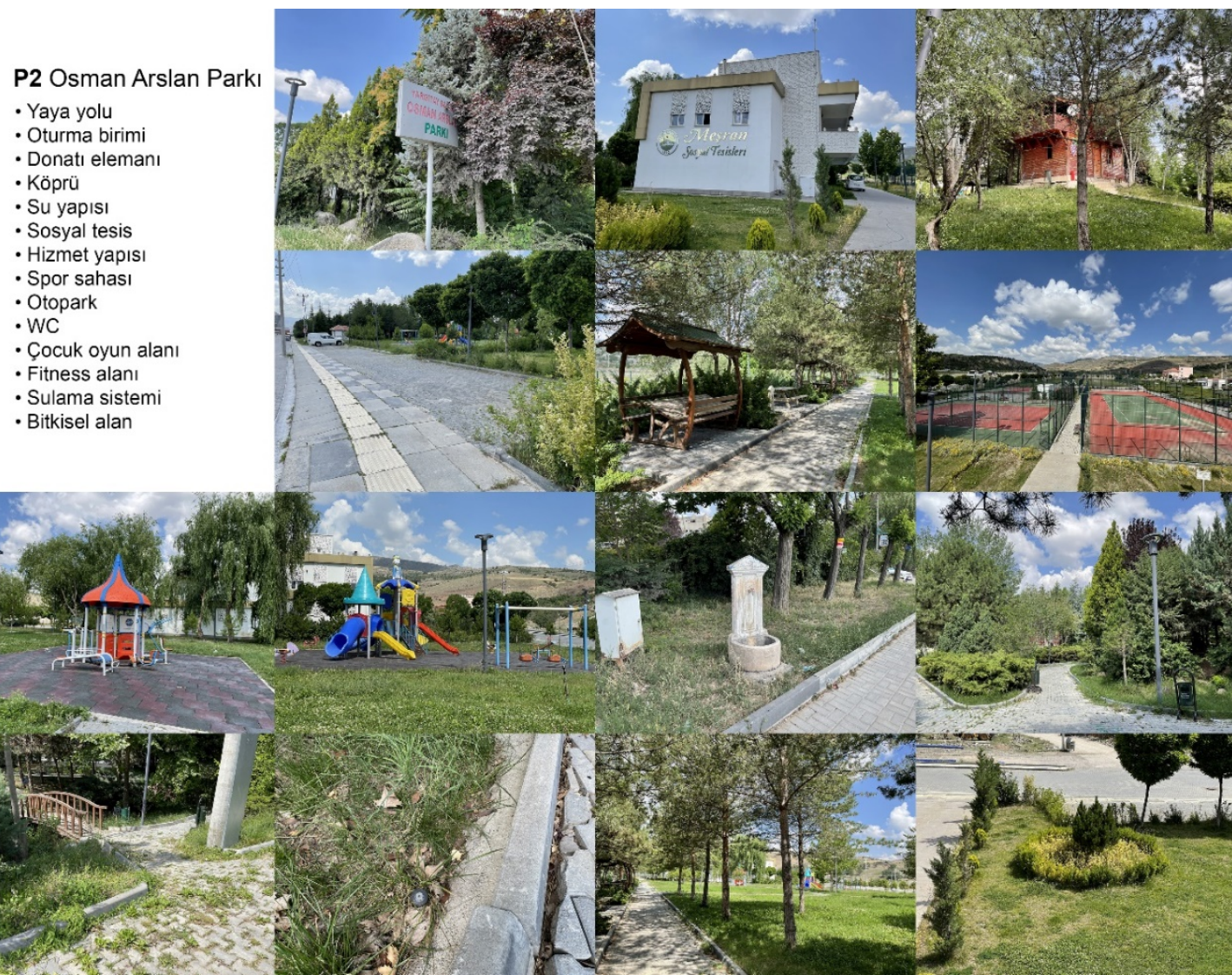

Şekil 5. P2 Osman Arslan Parkı peyzaj ögeleri listesi ve alandan görünümler
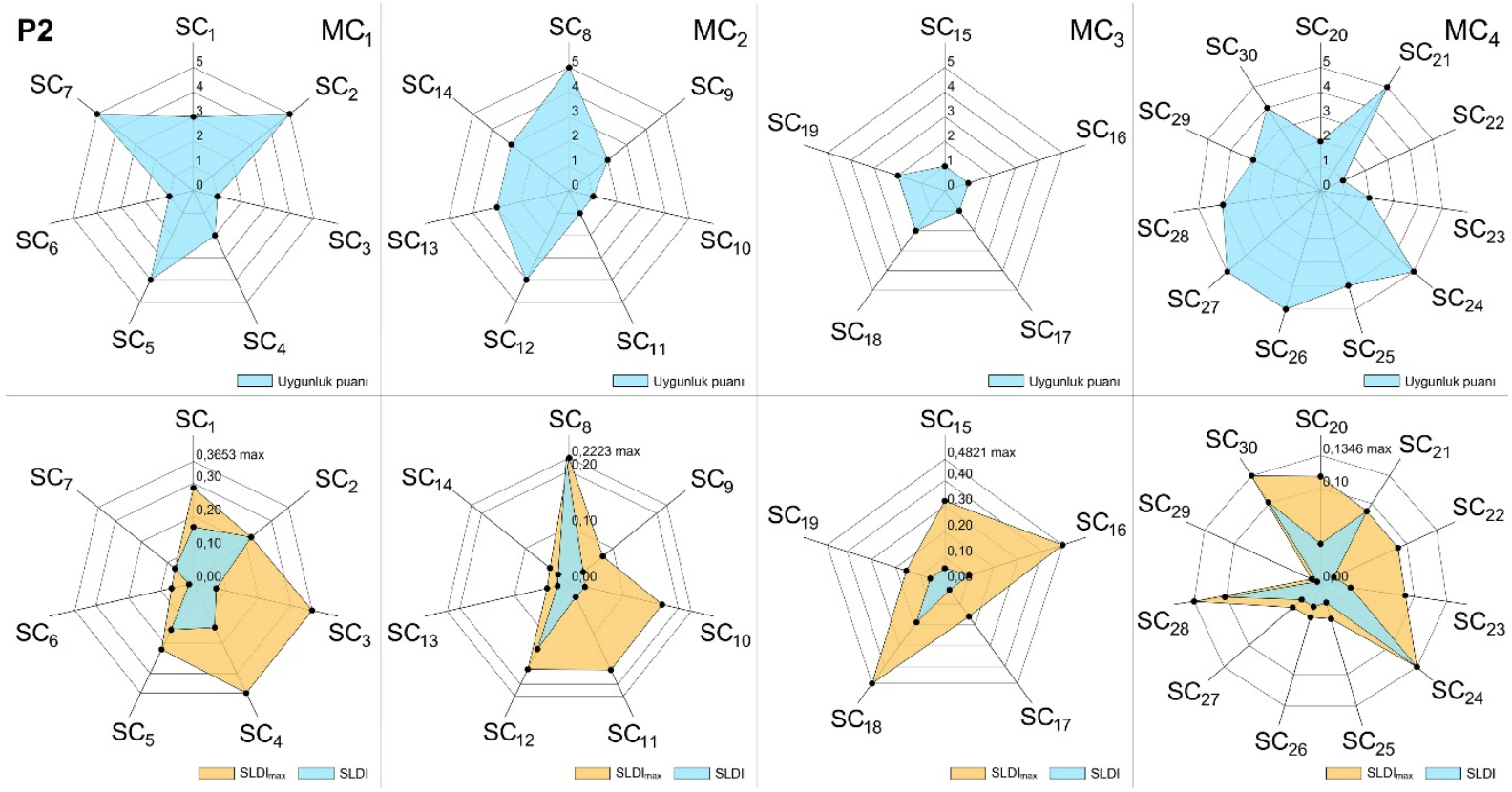

Şekil 6. P2 Osman Arslan Parkı SLDI diyagramları 


\section{P3 Atatürk Parkı}

Atatürk Parkı ilçe merkezinin güney girişinde yer almaktadır ve alanı yaklaşık $25.353 \mathrm{~m}^{2}$ 'dir. İlk olarak 1990 yılında hizmete açılmış ve ilerleyen yıllarda çeşitli yenileme çalışmaları yapılmış olup, ilçenin en eski parkıdır. Parktaki peyzaj ögeleri yaya yolları, oturma birimleri, donatı elemanları, süs havuzu, sosyal tesis ve hizmet binaları, spor sahaları, WC, çevre duvarı, çocuk oyun alanları, fitness alanları, koşu parkuru, sulama sistemi, geri dönüşüm noktası ve bitkisel alanlardır (Şekil 7).

Atatürk Park1 için hesaplanan SLDI değerlerine ilişkin diyagramlar Şekil 8'de görülmektedir. Diyagramdan $\mathrm{MC}_{1}$ Toprak ve vejetasyon incelendiğinde en yüksek SLDI'nın $\mathrm{SC}_{4}$ Uygun bitki kullanımı alt kriterine ait olduğu görülmektedir. Aynı zamanda tüm kriterler arasındaki en yüksek SLDI da bu kritere aittir. Bunu sirasıyla $\mathrm{SC}_{2} \mathrm{Sağl}_{1} \mathrm{kl}_{1}$ toprakları ve bitkileri koruma, $\mathrm{SC}_{5}$ Yerel türleri koruma ve kullanma, eşit değerlerle $\mathrm{SC}_{3}$ İstilacı bitkilerin kontrolü ve $\mathrm{SC}_{7}$ Is1 adası etkisini azaltma, $\mathrm{SC}_{1}$ Toprak yönetimi izlemektedir. $\mathrm{SC}_{6}$ Biyokütlenin optimizasyonu ise en düşük SLDI değerine sahip alt kriterdir. $\mathrm{MC}_{2}$ Materyal seçiminde ise $\mathrm{SC}_{8}$ Tehdit altındaki türlerden üretilen ahşap materyal kullanımını azaltma alt kriteri en yüksek, $\mathrm{SC}_{9}$ Mevcut yapı ve kaplamaları değerlendirme alt kriteri ise en düşük SLDI değerini almıştır. Diğer alt kriterler yüksekten düşüğe doğru, $\mathrm{SC}_{12}$ Yerel malzeme kullanımı, $\mathrm{SC}_{11}$ Geri dönüştürülmüş materyal kullanımı, $\mathrm{SC}_{10}$ Uyarlanabilir ve demonte konstrüksiyon, eşit değerlerle $\mathrm{SC}_{13}$ Az veya güvenli kimyasal madde kullanımı ile $\mathrm{SC}_{14}$ Sürdürülebilir materyal kullanımı şeklinde sıralanmıştır. $\mathrm{MC}_{3}$ Su diyagramında en yüksek SLDI değerini almış olan alt kriter $\mathrm{SC}_{15}$ Yağışın yerinde yönetimidir. Bunu sırasıyla eşit değerlerle $\mathrm{SC}_{16}$ Sulama suyu ihtiyacını azaltma ile $\mathrm{SC}_{18}$ Randımanlı sulama sistemi, yine eşit değerlerle $\mathrm{SC}_{17}$ Yağmur suyundan faydalanma ile $\mathrm{SC}_{19}$ Etkin drenaj sistemi izlemektedir. $\mathrm{MC}_{4}$ İnsan sağlığı ve refahı diyagramı incelendiğinde $\mathrm{SC}_{24}$ Yerel halka sosyal fayda sağlama ve $\mathrm{SC}_{28}$ Işı1k kirliliğini azaltma alt kriterlerinin ilk sırayı paylaştığı görülmektedir. Diğerleri ise yüksekten düşüğe doğru $\mathrm{SC}_{30}$ Yerel ekonomiyi destekleme, $\mathrm{SC}_{22}$ Güvenlik, $\mathrm{SC}_{23}$ Kolay anlaşılır sirkülasyon, $\mathrm{SC}_{20}$ Kültürel ve tarihi özellikleri koruma ve içerme, $\mathrm{SC}_{21}$ Erişilebilirlik, eşit değerlerle $\mathrm{SC}_{25}$ Zihinsel yenilenmeye katk1 sağlama, $\mathrm{SC}_{26}$ Fiziksel aktivite olanakları sunma ve $\mathrm{SC}_{27}$ Toplumsal iletişimi destekleme şeklinde sıralanmıştır. En düşük SLDI değerine sahip alt kriter olan $\mathrm{SC}_{29}$ Dumansı hava sahası sunma aynı zamanda tüm alt kriterler arasında da en düşüktür. 
P3 Atatürk Parkı

- Yaya yolu

- Oturma birimi

- Donati eleman

- Su yapısı

- Sosyal tesis

- Spor sahası

- WC

- Çevre duvar

- Güvenlik kameras

- Cocuk oyun alan

- Fitness alan

- Koşu parkuru

- Sulama sistemi

- Geri dönüšüm noktası

- Bitkisel alan
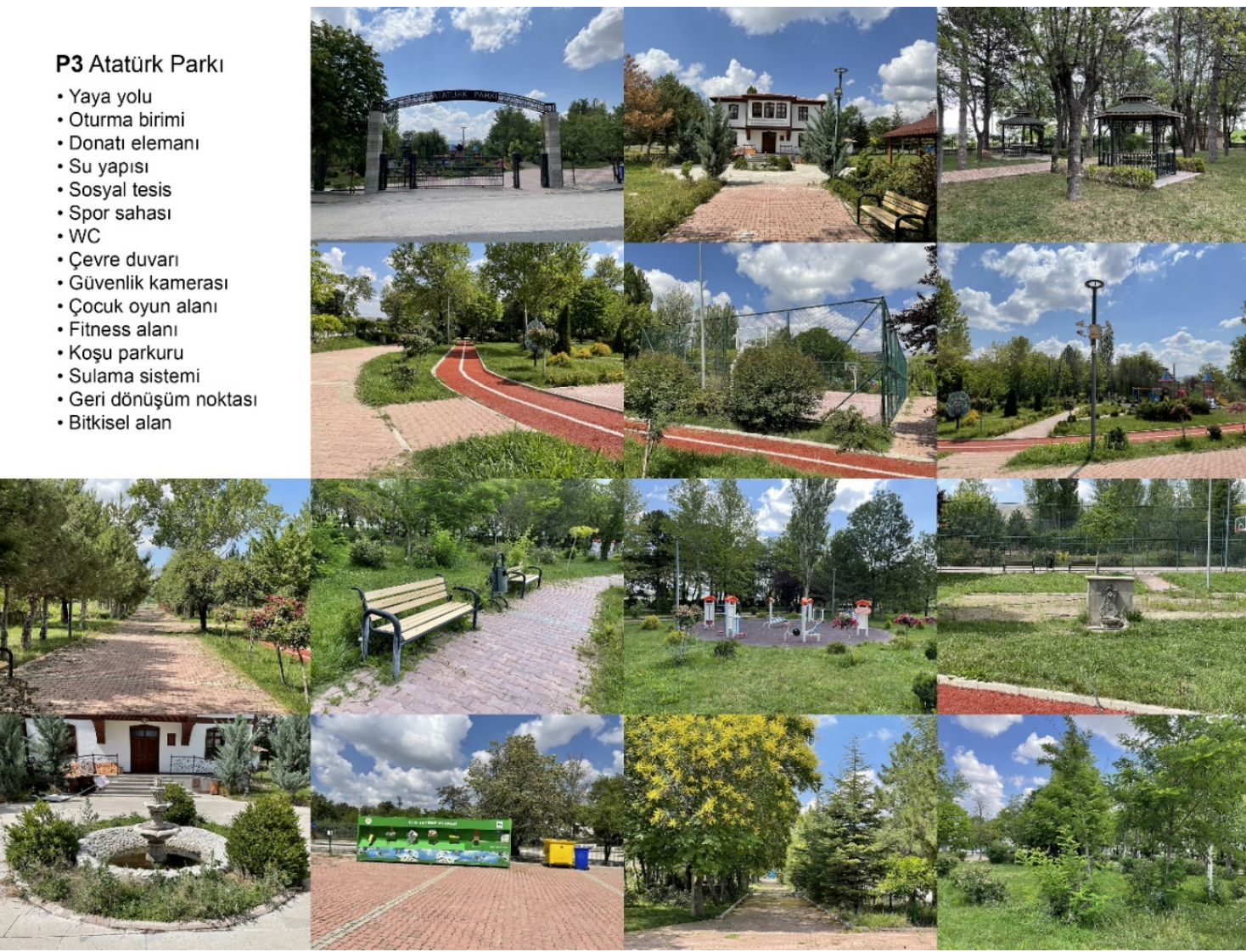

Şekil 7. P3 Atatürk Parkı peyzaj ögeleri listesi ve alandan görünümler

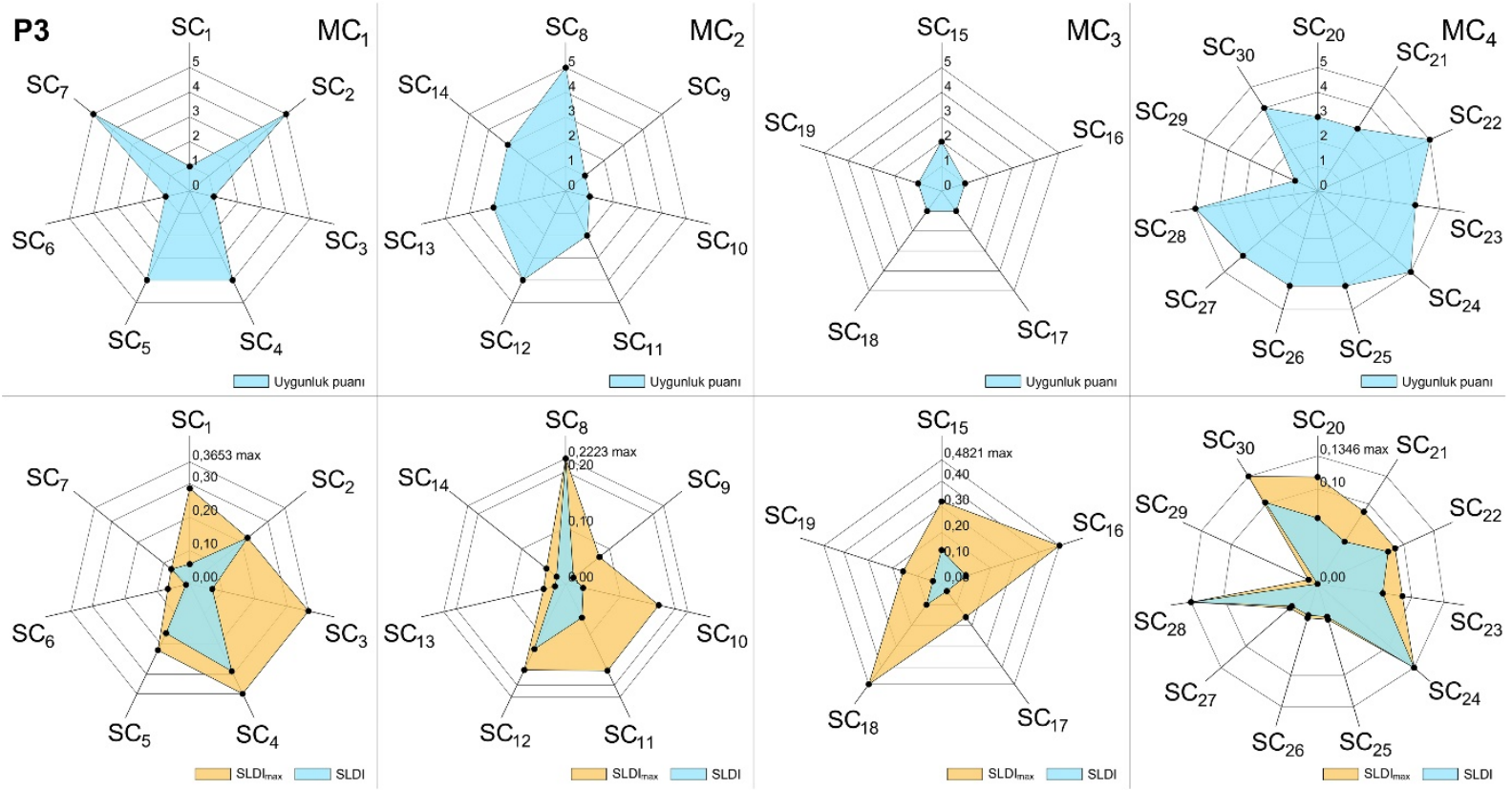

Şekil 8. P3 Atatürk Parkı SLDI diyagramları 


\section{SITES ve SLDI ${ }_{\text {ort }}$ kapsamında değerlendirme}

SITES, sürdürülebilir tasarımın toprak ve vejetasyona ilişkin bileşenleri kapsamında yapısal uygulama sırasında toprak bozulmalarını önlemeyi, sağlıklı bitkileri ve biyolojik toplulukları korumayı, su tutma kapasitesi ve infiltrasyonu desteklemeyi önermektedir. İstilacı türleri sahadan uzak tutmak suretiyle yerel ekosistemi desteklemek, saha koşullarına, iklime, ekolojiye ve tasarımın amacına uygun bitkileri kullanarak veya koruyarak peyzajın performansını artırmak, kaynak kullanımını azaltmak ve florayı geliştirmek gerekmektedir. Biyokütlenin optimize edilmesi su, azot, atmosferik gaz ve iklim kontrolü gibi faydalı ekosistem hizmetlerinin desteklenmesi açısından önemlidir. Bitki örtüsü ve yansıtıcı yüzeyler ile 1sı adası etkisi azaltılmalıdır (SITES, 2014). Sağlıklı toprak biyolojik olarak aktiftir ve flora ve fauna için yaşama ortamı sunma, besin döngüsünü sağlama, kirleticileri süzme ve tutma gibi hayati işlevlere sahiptir (Bullock ve Gregory, 2009). Fakat peyzaj uygulamaları sırasında çoğu zaman üst toprak kaybı, doğal drenaj sisteminin bozulması ve sıkışma gibi verimliliği baskılayan etkilere maruz kalmaktadır (Cook ve VanDerZanden, 2011). Tasarımda yapım veya alanın kullanımı sırasında toprağın sıkışmasını önleyecek unsur ve tekniklere yer verilmeli, toprağın tipine ve üzerindeki yaya, araç ve makine hareketlerine göre düzenlemeler yapılmalıdır (Thompson ve Sorvig, 2008). Bitkilerin tasarımdaki temel işlevleri ise mekân ve kimlik oluşturma, iklim kontrolü, fon oluşturma, çevreleme, vurgulama, yönlendirme, gürültü ve erozyon önleme (Dönmez vd., 2015; Hussain vd., 2014; Patil, 2013; Seçkin vd., 2011; Thompson ve Sorvig, 2008) olup, peyzaja biçim, doku ve renk katmaktadırlar (Shahli vd., 2014). Bitkiler, ekolojiye ve alanın gereksinimlerine uygun yerel türlerden seçilmeli ve mekânın özgün kimliğine katkı sunmalıdır (Patil 2013). Yerel bitki tür ve topluluklarının kullanılması sulama ve bakım maliyetlerini önemli ölçüde düşürür, bölgenin doğal mirasının korunmasına hizmet eder ve kullanıcıların sahiplenme ve aidiyet duygularını güçlendirir (Bean ve Yang, 2016). Bitkilerle kaplı, geçirimli (Drake vd., 2013) ve alanın albedosunu artıran açık renkli yüzeylerin (Hajimohammadipour, 2016) 1sı adası etkisini azalttığı bilinmektedir. Bu yüzeyler Birleşik Devletler Çevre Koruma Dairesi EPA (2012) tarafından soğuk kaplamalar olarak nitelendirilmiş ve 1sı adası etkisini azaltma stratejisi olarak kabul edilmiştir.

Şekil 9'da tüm parklar için ana faktörlerin ortalamasını ifade eden SLDI ort ve SLDI $_{\max }$ dörtgenleri aynı diyagramlar

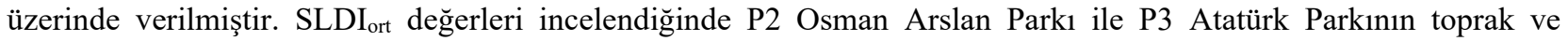
vejetasyon bakımından sürdürülebilirliği en yüksek parklar olduğu görülmektedir.
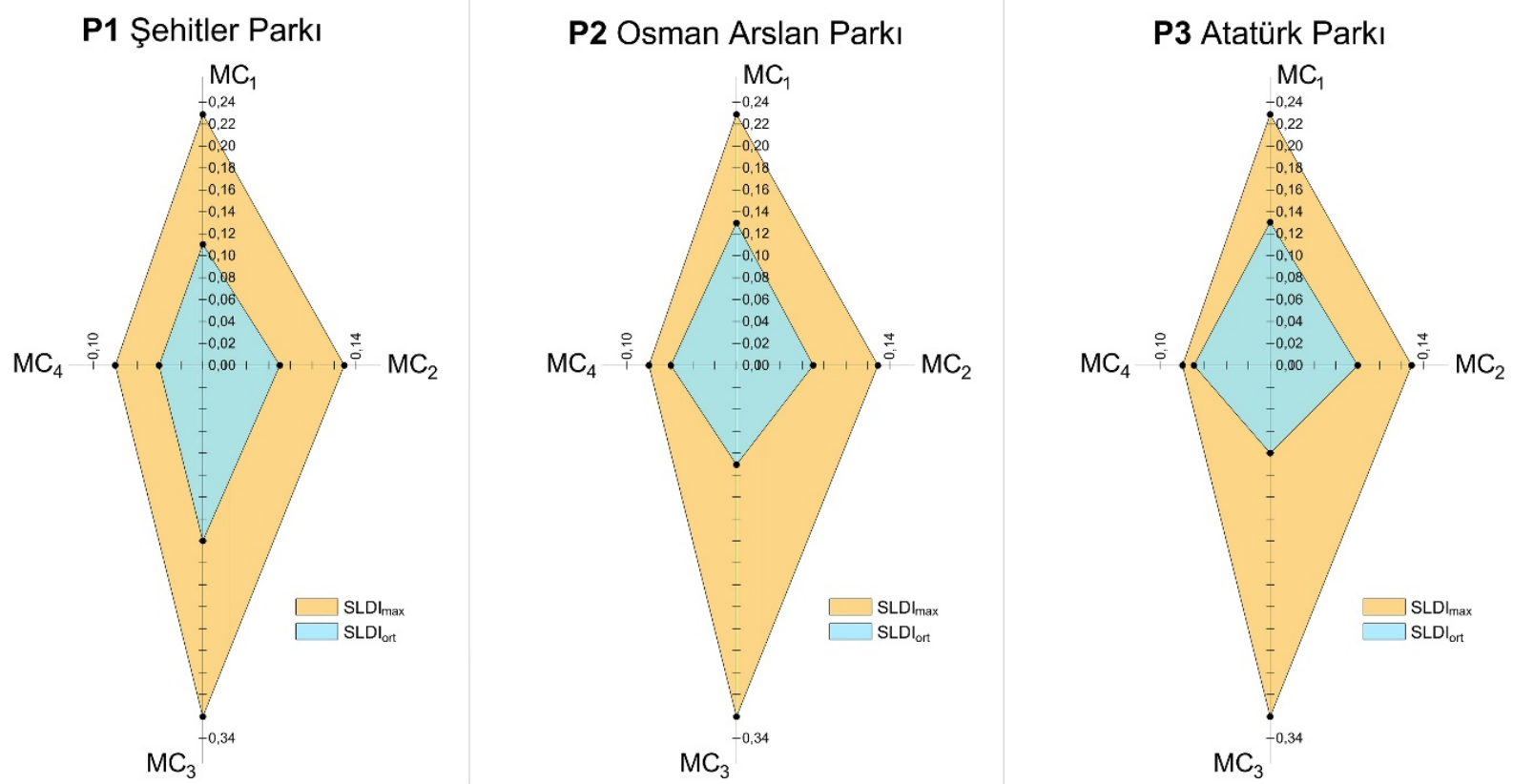

Şekil 9. Parkların SLDI ${ }_{\text {ort }}$ diyagramları 
Tehdit altında olmayan ağaç türlerinden elde edilmiş ahşap ürünleri kullanarak ekosistemler üzerindeki olumsuz etkileri minimize etmek ve yapı ve kaplamalara mevcut halleriyle yer vererek bunların yaşam döngülerini uzatmak, SITES'ın materyal seçimine ilişkin sürdürülebilir tasarım bileşenleri kapsamındadır. Ayrıca yenileme ve yapım süreçlerinde elde edilen inşaat atıklarını mümkün olduğunca sahada değerlendirmek, sağlam materyal ve bitkileri dolgu alanlarında heba etmemek, geri dönüştürülmüş ve işlenmemiş materyalleri tercih etmek suretiyle kaynak kullanımını azaltmak gerekmektedir. Bölgesel materyal, bitki ve toprak kullanarak nakliyelerden kaynaklı enerji tüketiminin azaltılması ve yerel kaynakların desteklenmesi, materyal seçiminde topluma, ekosistemlere ve kültürel değerlere saygıll ve sorumlu hammadde üretiminin dikkate alınması önemlidir. İnsan sağlı̆̆ı ve çevre üzerinde olumsuz etkileri olan kimyasal maddelerden ziyade daha güvenli olan alternatiflere yönelmeli, sürdürülebilirlik ilkelerine uygun faaliyet gösteren üreticiler ve tedarikçiler belirlenmeli ve işbirliği yapılmalıdır (SITES, 2014). Çoğu peyzaj düzenlemesi sert zeminler, çim alanlar ve süs bitkilerinden oluşur. Sert zemin materyalleri ve teknikleri içerisinde sürdürülebilirliğe katk1 sağlayacak birçok alternatif bulunmaktadır (Cook ve VanDerZanden, 2011). Yerel, az işlenmiş, üretim ve tedariğinde az enerji tüketilen, geri dönüştürülebilir, petrol bazlı olmayan, dayanıklı, toksik madde içermeyen ve karbondioksiti absorbe edebilen malzemeler tercih edilmelidir. Canlı ve uyum sağlayabilen materyallere, bitkisel çevreleme ve şev tutma yapılarına, sert zeminler yerine doğal yer örtücü kullanımına öncelik verilmeli, planlama ve tasarım sert zeminleri azaltacak, yüzey akışını önleyecek, geçirimli kaplamaların kullanımını teşvik edecek, sıcak yüzeyleri bitkilendirme ve doğru renk seçimi ile soğutacak önlemler içermelidir (Thompson ve Sorvig, 2008).

Şekil 9'da verilmiş olan SLDI $_{\text {ort }}$ değerlerine göre materyal seçimi bakımından tüm parklar birbirine yakın sürdürülebilirlik düzeyine sahiptir. Sürdürülebilirliği en yüksek park P3 Atatürk Parkıdır ve bunu P1 Şehitler Park1 ve P2 Osman Arslan Park1 takip etmektedir.

SITES'ın suya ilişkin sürdürülebilir tasarım bileşenleri kapsamında doğal hidrolojik koşullara benzer sistemlerle yağışı alanda tutarak su ekosistemleri ve doğal drenaj sistemleri üzerindeki baskının azaltılması önerilmektedir. Sulamada kullanılan içme suyu, yüzey ve yeraltı suyu miktarlarını azaltarak su kaynaklarının korunmalı ve enerji tüketimi minimize edilmelidir. Ayrıca görsel ve fiziksel olarak erişilebilir ve yağmur suyunu yerinde yönetmeyi mümkün kılan estetik açıdan çekici unsurları entegre ederek yerel iklim ve hidroloji ile bağlantı kurmak gerekmektedir (SITES, 2014). Sürdürülebilir yağmur suyu yönetiminin yağmur suyunu bir kaynak olarak kabul etme, geçirimsiz yüzeyleri azaltma, doğal özellikleri ve sistemleri koruma ve değerlendirme, sulama ve drenaj maliyetlerini düşürme, bu konuda halkı teşvik etme, ilgili idari birimlerle işbirliği yapma ve disiplinler arası çözümler üretme gibi temel prensipleri vardır (Kim ve Li, 2017). Tasarımda, alanın su tüketimin azaltmak için susuzluğa dayanıklı türlerin kullanıldığı kurakçıl peyzaj uygulamalarına (Aslan ve Yazıcı, 2016; Güvenç ve Demiroğlu, 2016; Şenol, 2019; Yurtsev, 2015) ve yüzey akışına geçen suyun toplanması, depolanması ve taşınması için fonksiyonel ve estetik çözümler sunan yağmur bahçelerine (Jaber vd., 2012; Müftüoğlu ve Perçin, 2015; Sert, 2013; Şenol, 2019) yer verilebilir. Etkin bir sulama sistemi yeşil alanların sürdürülebilirliği için kaçınılmaz altyapı unsurlarından biridir. Sulama sistemleri tasarım aşamasında planlanmalı ve diğer altyapı sistemleri ile birlikte inşa edilmelidir. Sonradan sistem eklemeye çalışmak alandaki yapısal ve bitkisel peyzaj elemanlarına zarar verir ve maliyeti artırır (Cook ve VanDerZanden, 2011).

Şekil 9'da verilmiş olan SLDI ${ }_{\text {ort }}$ değerlerine göre su ana kriteri bakımından P1 Şehitler Parkı önemli bir farkla en yüksek sürdürülebilirlik düzeyine sahiptir. Bunu birbirine yakın olacak şekilde P2 Osman Arslan Parkı ve P1 Şehitler Park1 takip etmektedir.

Tarihi yapıları, objeleri, kültürel peyzajı koruyarak alanın kimliğini öne çıkarmak, erişilebilirlik, güvenlik ve yön bulma unsurlarını tasarıma dâhil ederek kullanıcılara mekânı kolay anlama ve tanıma olanağı sunmak, halka açı etkinlikler ve tesisler oluşturarak topluma ekonomik ve sosyal fayda sağlamak SITES'ın insan sağlığı ve refahına ilişkin sürdürülebilirlik bileşenleri kapsamındadır. Ayrıca dinamik dış mekânlarla görsel ve fiziksel bağlantı kurmak ve buralarda fiziksel aktiviteyi teşvik etmek suretiyle insan sağlığı ve refahını iyileştirmek, topluluk aktiviteleri için uygun alanlar oluşturarak sosyal bağları güçlendirmek gerekmektedir. Gece görüşünü artıran, parlamayı ve ışığın insan sağlığı ve hareketleri üzerindeki olumsuz etkilerini azaltan tasarım unsurlarına yer verilmeli, kullanıcıların tütün dumanına maruz kalması engellenmeli, istihdam oluşturmak ve yerel materyal ve hizmet satın almak suretiyle halka ekonomik ve sosyal fayda sağlanmalıdır. Cook ve VanDerZanden (2011) tasarımın, kültürel ve tarihi özellikleri koruyacak unsurlara sahip olmasının, toplumun kültürel kimliğini ve aidiyet duygusunu güçlendirdiğini belirtmektedir. Sürdürülebilir tasarım aynı zamanda kullanıcılar ve bakım çalışmaları için erişimi ve dolaşımı kolaylaştıran girişler, araba ve yaya 
yolları ve otoparklar içermelidir Park alanlarının çoğunda birincil ve ikincil yaya yolları mevcuttur. Birincil yaya yolları daha geniş, aşınmaya ve yıpranmaya daha dayanıklı ve daha düzgün formlu yollar olmalıdır.

Şekil 9'daki SLDI ${ }_{\text {ort }}$ diyagramları insan sağlığı ve refahı bakımından tüm parkların yakın sürdürülebilirlik düzeylerine sahip olduklarını göstermektedir. Küçük farklarla yüksekten düşüğe doğru sıralama P3 Atatürk Parkı, P2 Osman Arslan Park1 ve P1 Şehitler Parkı şeklindedir. Şekilde SLDI $I_{\max }$ dörtgeni, tüm alt kriterlerin Likert ölçeğinde 5 tam puan aldığ varsayılarak oluşturulmuştur. SLDI ${ }_{\text {ort }}$ ve $S L D I_{\max }$ dörtgenleri karşılaştırıldığında P1 Şehitler Parkının sürdürülebilirliği en yüksek park olduğu görülse de genel olarak üç parkın da sürdürülebilirlik düzeyleri oldukça düşüktür.

\section{SONUÇ:}

Sürdürülebilirlik insan sağlığı, çevre ve doğal kaynakları doğrudan etkileyen birçok tasarım alanında olduğu gibi peyzaj tasarımında da önemli ve güncel kavramlardan biridir. Ülkeler sürdürülebilir yapı ve alan tasarımlarını sertifikalandırmak üzere çeşitli derecelendirme sistemleri geliştirmiştir. Bunlardan bazıları küresel ölçekte bazıları ise yerel sistemlerdir. Bu çalışma, yerleşim merkezlerindeki yapılı çevrenin önemli bileşenlerinden biri olan parkların, sürdürülebilir tasarım kapsamında değerlendirilmesine yönelik bir katsayı yöntemi ortaya koymaktadır. Geliştirilen SLDI, yeni parkların tasarımında veya mevcut parkların iyileştirilmesi ve sürdürülebilirlik düzeylerinin belirlenmesinde kullanılabilecek nicel bir gösterge olup, dikkate alınması gereken boyutları ve değişkenleri kolay anlaşılabilir ve karşılaştırılabilir hale getirmektedir. Yaygın olarak kullanılan sistemler genellikle mimari yapılara ve altyapıya yöneliktir. Bu çalışma ile aynı zamanda parklara uygun bir derecelendirme sistemi sunulmaktadır. Kriterlerin SITES Derecelendirme Sisteminden parklara ve bölgesel koşullara göre uyarlanmış olması, analizde Simos prosedürü uygulanarak çok kriterli karar verme mekanizmasının işletilmesi SLDI'nın güvenilirliğini artırmaktadır. SLDI, parkların işlevlerini belirlemek, korumak, geliştirmek ve devamlılı̆̆ını sağlamak için tasarımcı, plancı, yönetici, karar verici vb. tarafından bir ölçüm aracı olarak kullanılacaktır.

\section{Etik Standart ile Uyumluluk}

Çıkar Çatışması: Yazarlar herhangi bir çıkar çatışmasının olmadığını beyan eder.

Etik Kurul İzni: Bu çalışma için etik kurul iznine gerek yoktur.

\section{KAYNAKÇA:}

Aşılığlu, F. (2021). GISimos MCDA Land Suitability Model for Ecotourism Development. Journal of Environmental Engineering and Landscape Management, 29 (3), 200-214.

Aşılıoğlu, F., \& Memlük, Y. D. (2017). Determining and mapping eco-cultural subregions using GIS and Simos procedure. Journal of the Indian Society of Remote Sensing, 45 (3), 553-567.

Aşılığlu, F. (2016). Sustainable landscape design in contemporary residential gardens. In M. Özyavuz (Ed.), Environmental Sustainability and Landscape Management (pp. 19-32). Peter Lang GmbH.

Aslan, B. G., \& Yazıcı, K. (2016). Yeşil Altyapı Sistemlerinde Mevcut Uygulamalar. Ziraat Mühendisliği, 2016 (363), 31-37.

Bean, C., \& Yang, C.-H. (2016). Standards in Sustainable Landscape Architecture. Erişim Tarihi: 8 Haziran 2021 https://soa.utexas.edu/sites/default/disk/preliminary/preliminary/4-Bean_Yang-

Standards_in_Sustainable_Landscape_Architecture.pdf 
Bullock, P., \& Gregory, P. J. (2009). Soils - a neglected resource in urban areas. In P. Bullock \& P. J. Gregory (Eds.), Soils in the Urban Environment (pp. 1-5). Wiley-Blackwell.

Cook, T. W., \& VanDerZanden, A. M. (2011). Sustainable Landscape Management; Design, Construction, and Maintenance. John Wiley \& Sons, Inc.

Çınar, K. (2020). Kalecik Tarihi Kent Merkezinin Kültürel Peyzajlar Kapsamında Değerlendirilmesi [Yüksek Lisans Tezi, Ankara Üniversitesi Fen Bilimleri Enstitüsü, Peyzaj Mimarlı̆̆ı Ana Bilim Dalı]. Ankara.

de Sousa Pereira, L., \& Morais, D. C. (2020). Multicriteria Decision Model to Establish Maintenance Priorities for Wells in a Groundwater System. Water Resources Management, 34 (1), 377-392.

Dong-dong, Z., Yu-shan, S., \& Le, L. (2009). Study on Sustainable Landscape Design of Abandoned Quarries. Procedia Earth and Planetary Science, 1 (1), 1107-1113.

Dönmez, Özyavuz, M., \& Gökyer, E. (2015). Safranbolu Kentinin Konut ve Site Alanlarının Yeşil Alan Durumlarının Saptanması. İönü Üniversitesi Sanat Ve Tasarım Dergisi, 5 (11), 1-12.

Drake, J. A. P., Bradford, A., \& Marsalek, J. (2013). Review of environmental performance of permeable pavement systems: state of the knowledge. Water Quality Research Journal of Canada, 48 (3), 203-222.

EPA. (2012). Cool Pavements. Erişim Tarihi: 23 Mart 2021 https://www.epa.gov/heat-islands/heat-island-compendium

Figueira, J., \& Roy, B. (2002). Determining the weights of criteria in the ELECTRE type methods with a revised Simos' procedure. European Journal of Operational Research, 139 (2), 317-326.

Górecka, D. (2016). Using Sipres-A Fusion of the Revised Simos' Procedure and Zapros-in the Road Route Selection Process. Optimum. Economic Studies, 83 (5), 97-112.

Govindan, K., Kadziński, M., \& Sivakumar, R. (2017). Application of a novel PROMETHEE-based method for construction of a group compromise ranking to prioritization of green suppliers in food supply chain. Omega, 71, 129145.

Gürbüz, R., \& Arıdağ, L. (2013). Sürdürülebilir Peyzaj Tasarımı İçin ASLA Ve LEED Kriterlerinin Karşılaştırılması. Beykent Üniversitesi Fen ve Mühendislik Bilimleri Dergisi, 6 (2), 77-92.

Güvenç, İ., \& Demiroğlu, D. (2016). Kilis 7 Aralık Üniversitesi Merkez Yerleşkesi Yeşil Alanlarının “Xeriscape” (Kurakçıl Peyzaj Düzenlemesi) Açısından Değerlendirilmesi 3rd International Symposium on Environment and Morality 2016 (3. Uluslararası Çevre ve Ahlak Sempozyumu 2016 - ISEM2016), Antalya.

Hajimohammadipour, O. (2016). Açık Otoparklar Üzerine Bir Inceleme ve Tasarım Stratejilerinin Geliştirilmesi [Yüksek Lisans Tezi, İstanbul Teknik Üniversitesi, Fen Bilimleri Enstitüsü, Peyzaj Mimarlığı Ana Bilim Dalı]. İstanbul.

Hussain, M. R. M., Tukiman, I., Zen, I. H., \& Shahli, F. M. (2014). The Impact of Landscape Design on House Prices and Values in Residential Development in Urban Areas. APCBEE Procedia, 10, 316-320.

Jaber, F., Woodson, D., LaChance, C., \& York, C. (2012). Stormwater management: Rain gardens. Erişim Tarihi: 12 Temmuz 2021 https://agrilifecdn.tamu.edu/water/files/2013/02/stormwater-management-rain-gardens.pdf

Kats, G. (2003). Green building costs and financial benefits. Massachusetts Technology Collaborative. Erişim Tarihi: 29 Mart 2021 http://staging.community-wealth.org/sites/clone.community-wealth.org/files/downloads/paper-kats.pdf

Kim, H. W., \& Li, M.-H. (2017). Managing stormwater for urban sustainability: An evaluation of local comprehensive plans in the Chesapeake Bay watershed region. Journal of Environmental Planning and Management, 60 (10), 17021725 . 
Marzouk, M., Nouh, A., \& El-Said, M. (2014). Developing green bridge rating system using Simos' procedure. HBRC Journal, 10 (2), 176-182.

Mehta, V. (2014). Evaluating public space. Journal of Urban design, 19 (1), 53-88.

Merad, M., Dechy, N., Serir, L., Grabisch, M., \& Marcel, F. (2013). Using a multi-criteria decision aid methodology to implement sustainable development principles within an organization. European Journal of Operational Research, 224 (3), 603-613.

Müftüoğlu, V., \& Perçin, H. (2015). Sürdürülebilir Kentsel Yağmur Suyu Yönetimi Kapsaminda Yağmur Bahçesi. Inönü Universitesi Sanat Ve Tasarım Dergisi, 5 (11), 27-37.

Özyılmaz Küçükyağcı, P. (2020). Peyzaj Alanları Planlamasında SITES Sertifikasyon Sistemi. Kent Akademisi, 13 (3), 475-486.

Patil, P. R. (2013). Plant Selection Criteria for Landscaping in Gulbarga. International Journal of Research in Engineering and Technology, 2013 (Nov.), 428-430.

Reed, R., Bilos, A., Wilkinson, S., \& Schulte, K.-W. (2009). International comparison of sustainable rating tools. Journal of sustainable real estate, 1 (1), 1-22.

Ribas, J. R., \& da Silva Rocha, M. (2015). A decision support system for prioritizing investments in an energy efficiency program in favelas in the city of Rio de Janeiro. Journal of Multi-Criteria Decision Analysis, 22 (1-2), 89-99.

Seçkin, N. P., Seçkin, Y. Ç., \& Seçkin, Ö. B. (2011). Sürdürülebilir Peyzaj Tasarımı ve Uygulama İlkeleri (1 ed., Vol. 621). Literatür Yayınları.

Şenol, Y. (2019). Sürdürülebilir Peyzaj Tasarım Kriterleri Doğrultusunda Sultanbeyli Gölet Parkı çin Bir Model Önerisi [Yüksek Lisans Tezi, İstanbul Üniversitesi Cerrahpaşa Lisansüstü Eğitim Enstitüsü, Peyzaj Mimarlığı Ana Bilim Dal1 ]. İstanbul.

Sert, E. (2013). Enerji Etkin Kentsel Peyzaj Tasarımında Yağmur Suyu [Yüksek Lisans Tezi, İstanbul Teknik Üniversitesi Fen Bilimleri Enstitüsü]. İstanbul.

Shahli, F. M., Hussain, M. R. M., Tukiman, I., \& Zaidin, N. (2014). The Importance Aspects of Landscape Design on Housing Development in Urban Areas. APCBEE Procedia, 10, 311-315.

Shanian, A., Milani, A., Carson, C., \& Abeyaratne, R. (2008). A new application of ELECTRE III and revised Simos' procedure for group material selection under weighting uncertainty. Knowledge-Based Systems, 21 (7), 709-720.

SITES. (2014). Sustainable Sites Initiative, SITES v2 Rating System For Sustainable Land Design and Development. Green Business Certification Inc.

The Sustainable SITES Initiative. (2021). Homepage. Erişim Tarihi: 12 Şubat 2021 http://www.sustainablesites.org/

Thompson, W., \& Sorvig, K. (2008). Sustainable Landscape Construction: A Guide to Green Building Outdoors (2 ed.). Island Press.

TÜİK. (2020). Türkiye İstatistik Kurumu, Adrese Dayalı Nüfus Kayıt Sistemi Sonuçları. Erişim Tarihi: 3 Temmuz 2021 https://biruni.tuik.gov.tr/medas/?kn=95\&locale=tr

Turner, C., Frankel, M., \& Council, U. (2008). Energy performance of LEED for new construction buildings. New Buildings Institute, 4 (4), 1-42.

Ünal, S. G. (2014). Ankara Sinpaş Altınoran Konut Projesi ve Ekolojik Tasarım. Planlama, 24 (2), 95-106. 
Wilkens, I., \& Schmuck, P. (2012). Transdisciplinary Evaluation of Energy Scenarios for a German Village Using Multi-Criteria Decision Analysis. Sustainability, 4 (4), 1-26.

Yaşar, Y., \& Düzgüneş, E. (2013). Peyzaj Tasarımına Sürdürülebilirlik Kavramının Entegrasyonu: Bir Stüdyo Çalışması. Inönü Üniversitesi Sanat Ve Tasarım Dergisi, 7 (2013), 31-43.

Yurtsev, A. A. (2015). Sürdürülebilir Mimarlık Kapsamında Enerji Etkin Peyzaj Tasarım Yaklaşımları [Yüksek Lisans Tezi, Ege Üniversitesi Fen Bilimleri Enstitüsü Peyzaj Mimarlığı Ana Bilim Dalı ]. İzmir 